\title{
Review
}

\section{Antioxidant Activity of Foods: Development of Singlet Oxygen Absorption Capacity (SOAC) Assay Method}

\author{
Kazuo MUKAI \\ Department of Chemistry, Faculty of Science, Ehime University, Matsuyama 790-8577, Japan
}

(Received March 27, 2019)

\begin{abstract}
Summary Recently a new assay method that can quantify the singlet oxygen absorption capacity (SOAC) of antioxidants (AOs) and food extracts was proposed. Singlet oxygen $\left({ }^{1} \mathrm{O}_{2}\right)$ quenching rates $\left(k_{0}\right)$ and the relative SOAC values were measured for many carotenoids and phenolic AOs in ethanol/chloroform $/ \mathrm{D}_{2} \mathrm{O}(50: 50: 1, \mathrm{v} / \mathrm{v} / \mathrm{v})$ solution at $35^{\circ} \mathrm{C}$ using UVvis spectrophotometry. It has been clarified that the SOAC method is useful to evaluate the ${ }^{1} \mathrm{O}_{2}$-quenching activity of lipophilic and hydrophilic AOs having 5 orders of magnitude different rate constants $\left(k_{0}\right)$. Measurements of the $k_{0}$ and SOAC values were also performed for 39 kinds of food extracts. The results indicate that the SOAC method is useful to evaluate the ${ }^{1} \mathrm{O}_{2}$-quenching activity of food extracts having two orders of magnitude different $k_{Q}$ values. Further, the $k_{Q}$ values for the reaction of ${ }^{1} \mathrm{O}_{2}$ with 8 carotenoids and 8 vitamin E homologues were measured in an aqueous Triton X-100 (5.0 wt \%) micellar solution (pH 7.4). Results obtained demonstrate that the $k_{\mathrm{Q}}$ values of AOs in homogeneous and heterogeneous solutions vary notably depending on (i) polarity (dielectric constant $(\varepsilon)$ ) of the reaction field between $\mathrm{AOs}$ and ${ }^{1} \mathrm{O}_{2}$, (ii) local concentration of AOs, and (iii) mobility of AOs in solution. Measurements of $k_{Q}$ and SOAC values in a micellar solution may be useful for evaluating the ${ }^{1} \mathrm{O}_{2}$-quenching activity of AOs in biological systems. Furthermore, measurements of the SOAC values were performed for 32 kinds of food extracts using a microplate reader. The SOAC assay method was validated by inter-laboratory validation study due to 14 laboratories.
\end{abstract}

Key Words quenching rate, SOAC value, antioxidants, food extracts, carotenoids, vitamin E homologues, polyphenols, UV-vis spectrophotometry, microplate reader

Singlet oxygen $\left({ }^{1} \mathrm{O}_{2}\right)$ has attracted much attention as a biological oxidant $(1,2)$. In biological systems, ${ }^{1} \mathrm{O}_{2}$ is generated by type II photosensitization reaction, which is well known as the light-dependent ${ }^{1} \mathrm{O}_{2}$ generation mechanism $(3,4) .{ }^{1} \mathrm{O}_{2}$ is also generated by the lightindependent mechanisms: that is, the reaction between two peroxyl radicals (LOO·) (i.e. Russell mechanism) $(5,6)$ and the reaction of hypochlorite ion $\left(\mathrm{OCl}^{-}\right)$with hydrogen peroxide $\left(\mathrm{H}_{2} \mathrm{O}_{2}\right)$ in macrophage $(7,8)$. Further, ${ }^{1} \mathrm{O}_{2}$ generation by a cytochrome $c$ (cyt $c$ )-cardiolipin (CL) complex in a model membrane containing CL was proposed (9).

${ }^{1} \mathrm{O}_{2}$ reacts with many kinds of biological targets including lipids (10-12), proteins $(3,4)$, and DNA $(13-$ 15). Reactions with ${ }^{1} \mathrm{O}_{2}$ occur mainly by chemical reaction, inducing the degradation of biological systems. Many kinds of natural antioxidants (AOs) (such as carotenoids, vitamin E homologues, polyphenols, etc.) are widely present in foods, plants and biological systems (16-21) and may function as efficient ${ }^{1} \mathrm{O}_{2}$ quenchers (22-26).

Vitamin E homologues (i.e. D- $\alpha-, \beta-, \gamma-, \delta$-tocopherol and -tocotrienol $(\alpha-, \beta-, \gamma-, \delta$-Toc and -Toc-3)) can act as an efficient quencher of ${ }^{1} \mathrm{O}_{2}(27,28)$. It was shown

E-mail: mukai-k@dpc.ehime-u.ac.jp that $\alpha$-Toc quenches ${ }^{1} \mathrm{O}_{2}$ by a combination of physical quenching $\left(k_{\mathrm{q}}\right)$ and chemical reaction (chemical quenching, $k_{\mathrm{r}}$ ). Because $k_{\mathrm{q}} \gg k_{\mathrm{r}}$, the quenching process is almost entirely "physical," that is, $\alpha$-tocopherol deactivates $\sim 120{ }^{1} \mathrm{O}_{2}$ molecules before being destroyed by chemical reaction (Eq. (1)) (29).

$$
\begin{array}{r}
{ }^{1} \mathrm{O}_{2}+\text { Tocopherol } \stackrel{k_{Q}}{\rightarrow} \text { physical quenching }\left(k_{\mathrm{q}}\right) \\
+ \text { chemical reaction }\left(k_{\mathrm{r}}\right) \\
\left(k_{\mathrm{Q}}=k_{\mathrm{q}}+k_{\mathrm{r}}\right)
\end{array}
$$

As general phenolic AOs are easily soluble in ethanol, measurements of $k_{0}$ values were performed in ethanol, in previous works $(27,28)$. On the other hand, carotenoids (Cars) generally show low (or very low) solubility in ethanol, and, thus, ethanol/chloroform $/ \mathrm{D}_{2} \mathrm{O}$ (50:50:1, v/v/v) solution (abbreviated as "mixed solvent") was used for the measurements of the $k_{Q}$ values for Cars (30).

Recently, singlet oxygen absorption capacity (SOAC) assay method was developed in our laboratory, in order to evaluate the ${ }^{1} \mathrm{O}_{2}$-quenching activity of natural AOs and food and plant extracts $(28,31-36)$. The method is as follows: first, the second-order rate constants $\left(k_{0}\right)$ for the reaction of eight kinds of Cars and $\alpha$-Toc (Table 1) with ${ }^{1} \mathrm{O}_{2}$ were measured in mixed solvent, using the competition reaction method, where endoperoxide (EP) was 
Table 1. Second-order rate constants $\left(k_{Q}{ }^{A O}(S)\right.$ and $\left.k_{Q}{ }^{A O}\left(t_{1 / 2}\right)\right)$ of eight carotenoids and $\alpha$-tocopherol obtained from $S_{\text {blank }} /$ $S_{\mathrm{AO}}$ vs $[\mathrm{AO}]$ and $t_{1 / 2}{ }^{\mathrm{AO}} / t_{1 / 2}$ blank vs $[\mathrm{AO}]$ plots, respectively, relative rate constants $\left(k_{Q}{ }^{\mathrm{AO}}(S) / k_{Q}{ }^{\alpha-T_{0 c}}(S)\right)$, and relative SOAC values in ethanol/chloroform $/ \mathrm{D}_{2} \mathrm{O}$ solution.

\begin{tabular}{|c|c|c|c|c|}
\hline $\begin{array}{l}\text { Antioxidant } \\
\text { (AO) }\end{array}$ & $\begin{array}{l}k_{\mathrm{Q}}^{\mathrm{AO}}(S) \\
/ \mathrm{M}^{-1} \mathrm{~S}^{-1}\end{array}$ & $\begin{array}{l}k_{0}{ }^{\mathrm{AO}}\left(t_{1 / 2}\right) \\
/ \mathrm{M}^{-1} \mathrm{~S}^{-1}\end{array}$ & $k_{Q}{ }^{A O}(S) / k_{Q}{ }^{\alpha-\operatorname{Toc}}(S)$ & Relative SOAC value \\
\hline$\alpha$-Tocopherol & av $1.31 \times 10^{8 \mathrm{a}}$ & av $1.29 \times 10^{8 \mathrm{a}}$ & 1.00 & 1.00 \\
\hline Lyccopene & av $1.40 \times 10^{10 a}$ & av $1.23 \times 10^{10 a}$ & av $107^{b}$ & av $123^{b}$ \\
\hline Astaxanthin & av $1.17 \times 10^{10 a}$ & av $1.08 \times 10^{10 a}$ & av $89.3^{b}$ & av $109^{b}$ \\
\hline$\beta$-Carotene & av $1.08 \times 10^{10 \mathrm{a}}$ & av $1.02 \times 10^{10 a}$ & av $82.2^{\mathrm{b}}$ & av $95.8^{b}$ \\
\hline Capsanthin & $1.21 \times 10^{10}$ & $1.07 \times 10^{10}$ & 107 & 99.3 \\
\hline Zeaxanthin & $1.12 \times 10^{10}$ & $1.23 \times 10^{10}$ & 88.6 & 92.8 \\
\hline$\alpha$-Carotene & av $1.00 \times 10^{10 a}$ & av $9.20 \times 10^{9 a}$ & av $75.8^{\mathrm{b}}$ & av $92.4^{\mathrm{b}}$ \\
\hline Lutein & $8.07 \times 10^{9}$ & $7.31 \times 10^{9}$ & 67.9 & 73.8 \\
\hline$\beta$-Cryptoxanthin & $7.04 \times 10^{9}$ & $6.72 \times 10^{9}$ & 60.9 & 67.6 \\
\hline
\end{tabular}

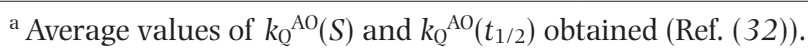

${ }^{\mathrm{b}}$ Experimental errors in the rate constants and relative SOAC values (av) were estimated to be $<10 \%$.

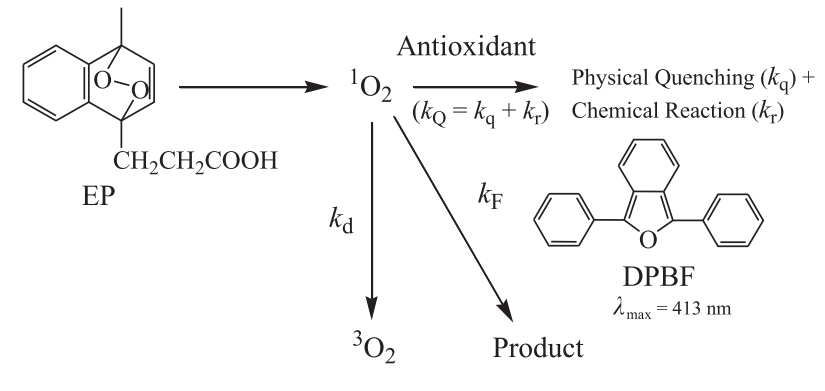

Scheme 1.

used as a ${ }^{1} \mathrm{O}_{2}$ generator and 2,5-diphenyl-3,4-benzofuran (DPBF) as an UV-vis absorption probe (see Scheme $1)(31,32)$. The rate constants, $k_{Q}(S)$ and $k_{Q}\left(t_{1 / 2}\right)$, were determined by analyzing the first-order rate constant $(S)$ and the half-life $\left(t_{1 / 2}\right)$ of the decay curve of DPBF, respectively, showing good accordance with each other, where an UV-vis spectrophotometer, equipped with a six-channel cell-positioner, was used for measurement.

Second, the measurements were performed for various phenolic AOs, containing vitamin E homologues and polyphenols in mixed solvent (Table 2) (33). Examples for the measurement of $k_{Q}(S)$ and $k_{Q}\left(t_{1 / 2}\right)$ values for $\gamma$-tocopherol and $\beta$-carotene were shown in Fig. 1 and Fig. 2, respectively. Third, the $k_{Q}(S)$ and $k_{Q}\left(t_{1 / 2}\right)$ values were also measured for many food and plant extracts containing various AOs $(28,34-36)$.

From the results, a new assay method that can quantify the SOAC of AOs, including Cars, phenolic AOs and food extracts, was proposed (31-33). Relative SOAC value was defined in the following way.

$$
\begin{aligned}
& \text { relative SOAC value } \\
&=\left\{\left(t_{1 / 2}{ }^{\mathrm{AO}}-t_{1 / 2} \text { blank }^{\prime} /\left(t_{1 / 2}{ }^{\alpha-\mathrm{Toc}}-t_{1 / 2}{ }^{\text {blank }}\right)\right\}\right. \\
& \times\{[\alpha \text {-Toc }] /[\mathrm{AOO}]\} \\
&= k_{Q}{ }^{\mathrm{AO}} / k_{\mathrm{Q}}{ }^{\alpha-T o c}
\end{aligned}
$$

where $[\alpha$-Toc] and $[\mathrm{AO}]$ are molar concentrations $(\mathrm{M}=\mathrm{mol} / \mathrm{L})$ (or weight concentrations $(\mathrm{g} / \mathrm{L}))$ of $\alpha$-Toc and AO, respectively. Equation (2) indicates that the AOs with fast ${ }^{1} \mathrm{O}_{2}$-quenching rate constants $\left(k_{\mathrm{Q}}\right)$ show large relative SOAC values (that is, high ${ }^{1} \mathrm{O}_{2}$-quenching activity and high antioxidant activity). $\alpha$-Tocopherol was used as a standard compound of SOAC assay. The reason was described in a previous study (31).

Further, measurements of the SOAC values for natural AOs (such as Cars, vitamin E homologues) and palm oil extracts were performed in an aqueous Triton X-100 (5.0 wt \%) micellar solution $\left(\mathrm{pH} 7.4,35^{\circ} \mathrm{C}\right)$, which was used as a simple model of biomembranes $(37,38)$.

The SOAC values were also measured for eight representative Cars, $\alpha$-Toc, and various vegetable and fruit extracts using a versatile instrument, the microplate reader $(39,40)$. A validation test was also performed for the above AOs (41).

\section{Materials}

Abbreviations used for AOs are as follows (see Table 1 (32) and Table 2 (33)): (i) Tocopherol derivatives: D- $\alpha$-, $\beta-, \gamma-, \delta$-tocopherol and -tocotrienols $(\alpha-, \beta-, \gamma-, \delta$-Tocs and -Toc-3s), tocol, and trolox. (ii) Caffeic acids: isoeugenol (IE), caffeic acid (CA), and ferulic acid (FA). (iii) Catechins and related compounds: epicatechin (EC), epigallocatechin (EGC), epicatechin gallate (ECG), epigallocatechin gallate (EGCG), 4-methylcatechol (4-MC), and 4-methyl gallate (4-MG). (iv) Carotenoids (Cars): astaxanthin (Ast), lutein (Lut), $\beta$-cryptoxanthin ( $\beta$-Cry), zeaxanthin (Zea), capsanthin (Cap), $\alpha$ - and $\beta$-carotene ( $\alpha$ - and $\beta$-Car), and lycopene (Lyc). (v) The others: ubiquinol-10 $\left(\mathrm{UQ}_{10} \mathrm{H}_{2}\right)$ and vitamin $\mathrm{C}($ Vit $\mathrm{C})$.

DPBF was obtained from Tokyo Kasei Organic Chemicals, Japan. 3-(1,4-Epidioxy-4-methyl-1,4-dihydro-1naphthyl)propionic acid (endoperoxide, EP) (Scheme 1) was obtained from Wakenyaku Co. Ltd., Japan. The result of the measurement of the UV spectrum of EP indicates that the powder sample of EP includes 95\% EP and 5\% EP-precursor unreacted $(31,32)$.

\section{Measurements of Rate Constants ( $\left.k_{Q}\right)$ and Molar Extinction Coefficient ( $\boldsymbol{\varepsilon}_{\text {max }}$ )}

Measurements of rate constants $\left(k_{0}\right)$ were performed 
A

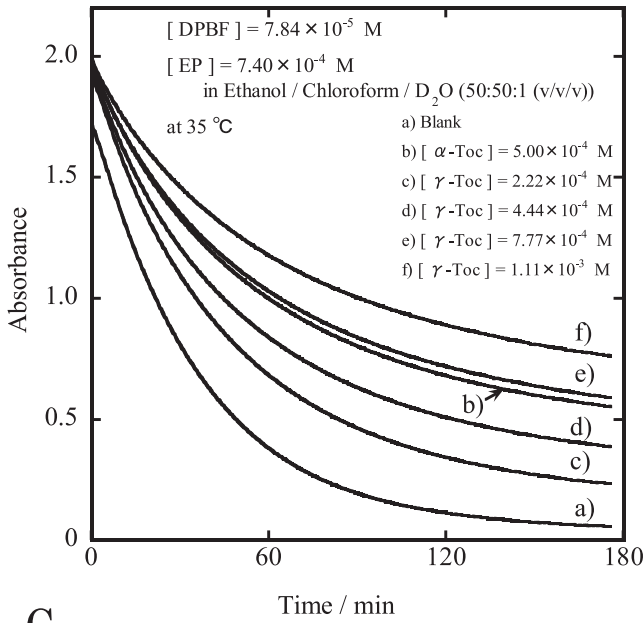

C

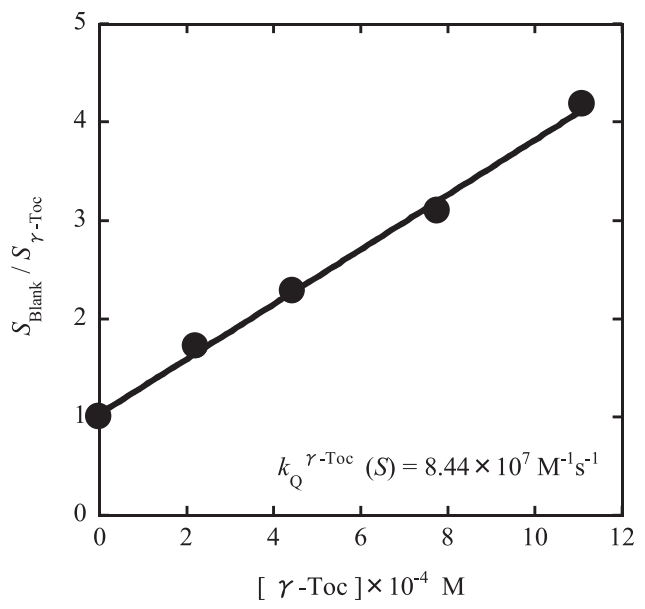

B

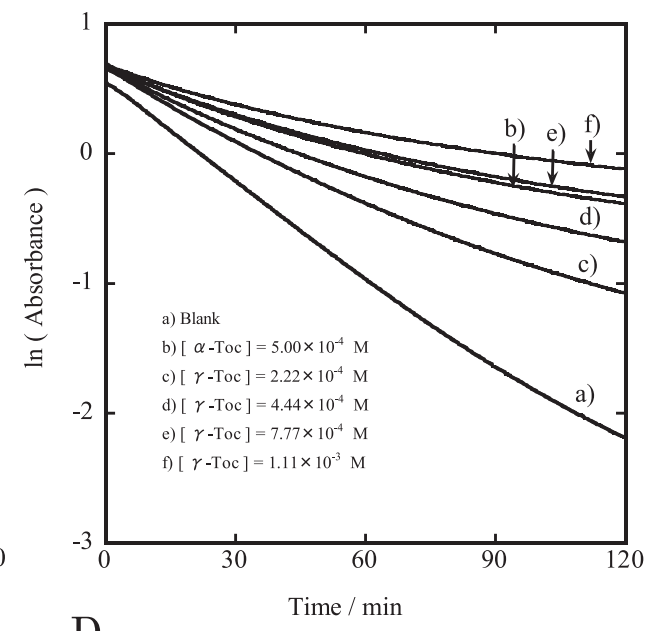

D

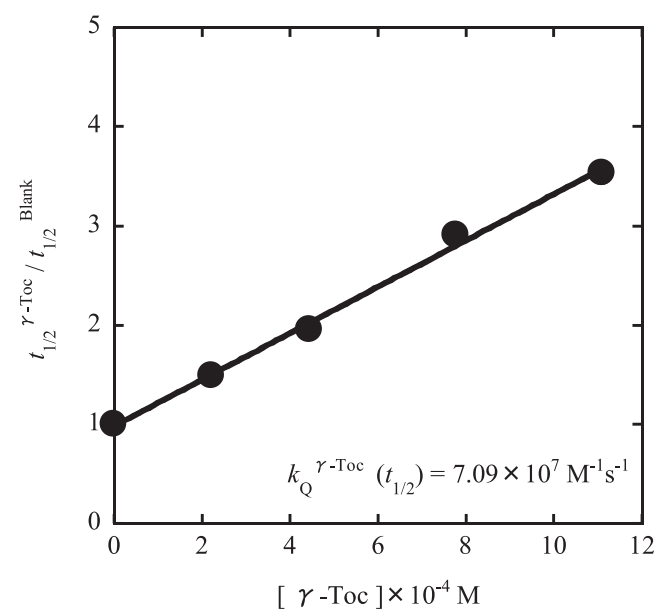

Fig. 1. (A) Change in absorbance of DPBF at $413 \mathrm{~nm}$ during the reaction of DPBF with ${ }^{1} \mathrm{O}_{2}$ in the absence and presence of sample $(\alpha$ - or $\gamma$-tocopherol $)$ in ethanol/chloroform $/ \mathrm{D}_{2} \mathrm{O}$ solution at $35^{\circ} \mathrm{C}$. $[\mathrm{DPBF}]_{t=0}=7.84 \times 10^{-5} \mathrm{M}$ and $[\mathrm{EP}]_{t=0}=7.40 \times 10^{-4} \mathrm{M}$. The values of $[\alpha-\mathrm{Toc}]_{t=0}$ and $[\gamma-\mathrm{Toc}]_{t=0}$ are shown in A. (B) Plot of ln (Absorbance) vs time. (C) Plot of $S_{\text {blank }} / S_{\gamma \text {-Toc vs }}[\gamma$-Toc $]$. (D) Plot of $t_{1 / 2}{ }^{\gamma \text {-Toc } / t_{1 / 2}}{ }^{\text {blank }}$ vs $[\gamma-$-Toc $]$.

in (i) ethanol/chloroform $/ \mathrm{D}_{2} \mathrm{O}(50: 50: 1, \mathrm{v} / \mathrm{v} / \mathrm{v})$, (ii) ethanol, and (iii) an aqueous Triton X-100 micellar (5.0 wt \%) solution $(\mathrm{pH}=7.4)$ by using a Shimadzu UV-vis spectrophotometer (UV-1800) (Kyoto, Japan), equipped with a six-channel cell-positioner and an electron-temperature control unit (CPS-240A). A microplate reader (SH-9000Lab; Corona Electric, Ibaraki, Japan) was also used for the measurement of $k_{Q}$ value $(39,40)$. All the measurements were performed at $35.0 \pm 0.5^{\circ} \mathrm{C}$. Detailed experimental conditions used for measurements were described in previous works (31, $32,39)$. The values of molar extinction coefficient $\left(\varepsilon_{\max }\right)$ of Cars were determined, using Lambert-Beer's equation $\left(\right.$ Absorbance $=\varepsilon_{\max }[$ Carotenoid] $)$.

\section{Analyses of the Second-Order Rate Constants $\left(k_{Q}{ }^{A O}(S)\right.$ and $\left.k_{Q}{ }^{A O}\left(t_{1 / 2}\right)\right)$}

The rate constant $k_{0}{ }^{\mathrm{AO}}(S)$ for the reaction of ${ }^{1} \mathrm{O}_{2}$ with $\mathrm{AO}$ was determined by Eq. (3), as reported in previous studies $(31,32,42,43)$.

$S_{\text {blank }} / S_{\mathrm{AO}}=1+\left\{k_{0}{ }^{\mathrm{AO}}(S)[\mathrm{AO}]\right\} / k_{\mathrm{d}}$

where $S_{\text {blank }}$ and $S_{\mathrm{AO}}$ are slopes of the first-order plots (that is, ln (Absorbance) vs time plots) of disappearance of DPBF in the absence and presence of AO, respectively (Fig. 1B). $k_{\mathrm{d}}$ is the rate of natural deactivation of ${ }^{1} \mathrm{O}_{2}$ in the ethanol/chloroform $/ \mathrm{D}_{2} \mathrm{O}\left(k_{\mathrm{d}}=3.03 \times 10^{4}\right)(26)$ and ethanol $\left(k_{\mathrm{d}}=8.3 \times 10^{4} \mathrm{~s}^{-1}\right)(44)$. Equation (3) indicates that the $k_{0}{ }^{\mathrm{AO}}(S)$ value can be obtained from $S_{\text {blank }} / S_{\mathrm{AO}}$ versus [AO] plot (Fig. 1C).

We can easily obtain Eq. (4), by substituting the relation for the first-order reaction $\left(t_{1 / 2}{ }^{\mathrm{AO}}=\ln 2 / S_{\mathrm{AO}}\right)$ into Eq. (3).

$$
t_{1 / 2}{ }^{\mathrm{AO}} / t_{1 / 2} \text { blank }=1+\left\{k_{\mathrm{Q}}^{\mathrm{AO}}\left(t_{1 / 2}\right)[\mathrm{AO}]\right\} / k_{\mathrm{d}}
$$

where $t_{1 / 2}$ blank and $t_{1 / 2}{ }^{\mathrm{AO}}$ are the half-lives of DPBF in the absence and presence of AO, respectively (Fig. 1A). Equation (4) indicates that the $k_{Q}{ }^{\mathrm{AO}}\left(t_{1 / 2}\right)$ value can be obtained from $t_{1 / 2} \mathrm{AO}^{\mathrm{O}} / t_{1 / 2}$ blank vs [AO] plot (Fig. 1D). If $\mathrm{AO}$ is $\alpha$-Toc, we can obtain similar Eq. (5) for $\alpha$-Toc.

$$
t_{1 / 2}{ }^{\alpha-\operatorname{Toc}} / t_{1 / 2}{ }^{\text {blank }}=1+\left\{k_{Q}{ }^{\alpha-\operatorname{Toc}}\left(t_{1 / 2}\right)[\alpha-\operatorname{Toc}]\right\} / k_{\mathrm{d}}
$$

\section{Development of Singlet Oxygen Absorption Capacity (SOAC) Assay Method}

By eliminating $k_{d}$ from Eqs. (4) and (5), we can obtain the following relation. 
Table 2. The $k_{Q}{ }^{A O}(S)$ and $k_{Q}{ }^{A O}\left(t_{1 / 2}\right)$ values for many kinds of antioxidants (AO) in ethanol/chloroform $/ \mathrm{D}_{2} \mathrm{O}$ solution at $35.0^{\circ} \mathrm{C}$, relative rate constants $\left(k_{Q}{ }^{A O}(S) / k_{Q}{ }^{\alpha-T o c}(S)\right)$, and relative SOAC values.

\begin{tabular}{|c|c|c|c|c|}
\hline $\begin{array}{l}\text { Antioxidant } \\
\text { (AO) }\end{array}$ & $\begin{array}{l}k_{Q^{A O}}{ }^{\mathrm{AO}}(S)^{\mathrm{a}} \\
/ \mathrm{M}^{-1} \mathrm{~S}^{-1}\end{array}$ & $\begin{array}{c}k_{0}{ }^{A O}\left(t_{1 / 2}\right)^{\mathrm{a}} \\
/ \mathrm{M}^{-1} \mathrm{~S}^{-1}\end{array}$ & $k_{Q}{ }^{A O}(S) / k_{Q}{ }^{\alpha-\operatorname{Toc}}(S)$ & Relative SOAC value ${ }^{\mathrm{a}}$ \\
\hline$\alpha$-Toc 1 & $1.31 \times 10^{8}$ & $1.29 \times 10^{8}$ & 1.00 & 1.00 \\
\hline b-Toc 2 & $9.30 \times 10^{7}$ & $8.34 \times 10^{7}$ & 0.710 & $0.806-0.922$ (av 0.866) \\
\hline$\gamma$-Toc 3 & $8.44 \times 10^{7}$ & $7.09 \times 10^{7}$ & 0.644 & $0.666-0.764$ (av 0.706) \\
\hline$\delta$-Toc 4 & $4.11 \times 10^{7}$ & $3.86 \times 10^{7}$ & 0.314 & $0.369-0.394$ (av 0.380) \\
\hline tocol 5 & $1.84 \times 10^{7}$ & $1.61 \times 10^{7}$ & 0.140 & $0.149-0.174($ av 0.162$)$ \\
\hline trolox 6 & $4.20 \times 10^{7}$ & $3.66 \times 10^{7}$ & 0.321 & $0.327-0.369$ (av 0.349) \\
\hline $\mathrm{UQ}_{10} \mathrm{H}_{2} 7$ & $6.22 \times 10^{7}$ & $5.86 \times 10^{7}$ & 0.475 & $0.468-0.594($ av 0.521$)$ \\
\hline IE 8 & $2.98 \times 10^{6}$ & $2.53 \times 10^{6}$ & 0.0227 & $0.0242-0.0278$ (av 0.0258) \\
\hline CA 9 & $6.85 \times 10^{5}$ & $5.85 \times 10^{5}$ & 0.00523 & $0.00637-0.00679($ av 0.00659$)$ \\
\hline FA 10 & $2.71 \times 10^{5}$ & $2.08 \times 10^{5}$ & 0.00207 & $0.00217-0.00257$ (av 0.00228$)$ \\
\hline EC 11 & $8.31 \times 10^{6}$ & $7.85 \times 10^{6}$ & 0.0634 & $0.0724-0.0814$ (av 0.0752) \\
\hline EGC 12 & $1.31 \times 10^{7}$ & $1.30 \times 10^{7}$ & 0.100 & $0.117-0.129$ (av 0.122) \\
\hline ECG 13 & $4.94 \times 10^{6}$ & $3.61 \times 10^{6}$ & 0.0377 & $0.0367,0.0383($ av 0.0375$)$ \\
\hline EGCG 14 & $5.05 \times 10^{6}$ & $4.27 \times 10^{6}$ & 0.0385 & $0.0442,0.0405$ (av 0.0424) \\
\hline 4-MC 15 & $4.96 \times 10^{6}$ & $4.12 \times 10^{6}$ & 0.0379 & $0.0421-0.0495$ (av 0.0474) \\
\hline 4-MG 16 & $1.34 \times 10^{5}$ & $1.05 \times 10^{5}$ & 0.00102 & $0.00114-0.00126($ av 0.00119$)$ \\
\hline Vit C 17 & $1.92 \times 10^{6}$ & $1.88 \times 10^{6}$ & 0.0147 & $0.016,0.016($ av 0.016$)$ \\
\hline
\end{tabular}

${ }^{\mathrm{a}}$ The experimental errors in the rate constants $\left(k_{\mathrm{Q}}{ }^{\mathrm{AO}}(S)\right.$ and $\left.k_{\mathrm{Q}}{ }^{\mathrm{AO}}\left(t_{1 / 2}\right)\right)$ and relative SOAC values were estimated to be $<10 \%$ (see Refs. (31) and (32)).

$$
\begin{gathered}
\left(t_{1 / 2}{ }^{\mathrm{AO}}-t_{1 / 2}{ }^{\text {blank }}\right) /\left(t_{1 / 2}{ }^{\alpha-\text { Toc }}-t_{1 / 2}{ }^{\text {blank }}\right) \\
=k_{Q}{ }^{\mathrm{AO}}[\mathrm{AO}] / k_{\mathrm{Q}}{ }^{\alpha-\mathrm{Toc}}[\alpha-\text { Toc }]
\end{gathered}
$$

Equation (6) indicates that the half-life $\left(t_{1 / 2}{ }^{\mathrm{AO}}\right)$ of the AO increases linearly with increasing the concentration of the AO and depends on the product of $k_{Q}{ }^{A O}$ and [AO], if the concentration of $\alpha$-Toc is constant. From Eq. (6), we can derive Eq. (2) and define the relative SOAC value. Equation (2) indicates that the SOAC value corresponds to the ratio $\left(k_{\mathrm{Q}}{ }^{\mathrm{AO} /} k_{\mathrm{Q}}{ }^{\alpha-\mathrm{Toc}}\right)$ of the quenching rate $\left(k_{\mathrm{Q}}{ }^{\mathrm{AO}}\right)$ of ${ }^{1} \mathrm{O}_{2}$ by AO to that $\left(k_{\mathrm{Q}}{ }^{\alpha-\mathrm{Toc}}\right)$ by $\alpha$-Toc. According to Eq. (2), the SOAC value was determined by the measurement of the half-life $\left(t_{1 / 2}\right)$ of DPBF.

\section{5. ${ }^{1} \mathrm{O}_{2}$-Quenching Rates $\left(\mathrm{k}_{Q}(S)\right.$ and $\left.k_{Q}\left(t_{1 / 2}\right)\right)$ and SOAC Values for 16 Phenolic Antioxidants}

Measurements of $k_{0}(S), k_{0}\left(t_{1 / 2}\right)$, and SOAC values were performed for 16 kinds of phenolic AOs, including tocopherol derivatives $(\alpha-, \beta-, \gamma-, \delta$-Toc, tocol, trolox), ubiquinol-10, caffeic acids (IE, CA, FA), and Vit C (Table 2) (33). Figure $1 \mathrm{~A}$ shows an example of measurement of the reaction between DPBF and EP in the absence ((a) blank) and presence of AOs ((b) $[\alpha$-Toc $]=5.00 \times 10^{-4} \mathrm{M}$, (c) $[\gamma$-Toc $]=2.22 \times 10^{-4} \mathrm{M}$, (d) $[\gamma$-Toc $]=4.44 \times 10^{-4} \mathrm{M}$, (e) $[\gamma$-Toc $]=7.77 \times 10^{-4} \mathrm{M}$, (f) $[\gamma$-Toc $]=1.11 \times 10^{-3} \mathrm{M}$ ) in mixed solvent at $35^{\circ} \mathrm{C}$. The disappearance of DPBF at $\lambda_{\max }=413 \mathrm{~nm}$ due to the chemical reaction with ${ }^{1} \mathrm{O}_{2}$ was observed. The values of first-order decay rate constant $\left(S_{\text {blank }}, S_{\alpha \text {-Toc }}, S_{\gamma \text {-Toc }}\right)$ (Table 3 ) were estimated by analyzing the decay curve of DPBF, as shown in Fig. 1B. The analysis of the decay curve was performed at $\sim 5<t<\sim 60 \mathrm{~min}$. This is an important condition to obtain the correct rate constant $\left(k_{Q}\right)$ for AOs (31-33). The values of half-life $\left(t_{1 / 2}^{\alpha-T o c}, t_{1 / 2}^{\gamma-\text { Toc }}, t_{1 / 2}{ }^{\text {blank }}\right)$ were calculated carefully according to the method described in a previous work (31). The values obtained are summarized in Table 3.

Plots of $S_{\text {blank }} / S_{\gamma \text {-Toc }}$ and $t_{1 / 2}{ }^{\gamma \text {-Toc }} / t_{1 / 2}{ }^{\text {blank }}$ vs $[\gamma$-Toc $]$ are shown in Fig. 1C and D, respectively. The $k_{0}{ }^{\gamma \text {-Toc }}(S)$ and $k_{0}{ }^{\gamma-\operatorname{Toc}}\left(t_{1 / 2}\right)$ values obtained by using Eqs. (3) and (4) are $8.44 \times 10^{7}$ and $7.09 \times 10^{7} \mathrm{M}^{-1} \mathrm{~s}^{-1}$, respectively. As the measurements were performed for one concentration of $\alpha$-Toc and four concentrations of $\gamma$-Toc (AO- $1-$ AO-4), we can determine four sets of relative SOAC values, using Eq. (2) (Table 3). The relative SOAC values $(0.666-0.764$, av $=0.706)$ obtained for $\gamma$-Toc are similar to each other and agree well with the ratio of the quenching rate constant of $\gamma$-Toc to that of $\alpha$-Toc $\left(k_{\mathrm{Q}}{ }^{\gamma \text {-Toc }}(S) / k_{\mathrm{Q}}{ }^{\alpha \text {-Toc }}(S)=0.644\right)$, as expected from Eq. (2). Similar measurements were performed for $\beta$ - and $\delta$-Toc, tocol, trolox, and ubiquinol-10. The rate constants $\left(k_{\mathrm{Q}}{ }^{\mathrm{AO}}(S)\right.$ and $\left.k_{\mathrm{Q}}{ }^{\mathrm{AO}}\left(t_{1 / 2}\right)\right)$ and the relative SOAC values obtained are listed in Table 2 .

On the other hand, in the case of FA, the rate constant $\left(k_{0}(S)\right)$ is two-three orders of magnitude smaller than that of $\gamma$-Toc (Table 2). Consequently, we had to use two-three orders of magnitude higher concentrations to obtain reliable $k_{\mathrm{Q}}(S)$ and SOAC values, as anticipated from Eqs. (3) and (6), respectively (see Table 3). We could not obtain the reliable SOAC value, when the difference between the half-lives of $\mathrm{AO}$ and blank $\left(t_{1 / 2}{ }^{\mathrm{AO}}-t_{1 / 2}{ }^{\text {blank }}\right)$ (that is, the value of a numerator in Eq. (6)) was smaller than $\sim 5$ min (data are not shown) (33). The rate constants and the SOAC values obtained for caffeic acids (IE, CA, and FA) are summarized in Tables 2 and 3.

Similar measurements were performed for EC, EGC, ECG, EGCG, 4-MC, and 4-MG, by varying concentrations 
Table 3. Employed concentrations, first-order decay rates $(S)$, and half-lives ( $\left.t_{1 / 2}\right)$ of blank (DPBF only), $\alpha$-tocopherol, and antioxidants (AOs) ((a) $\gamma$-tocopherol, (b) ferulic acid, (c) epicatechin, and (d) epicatechin gallate) and relative SOAC values in ethanol/chloroform $/ \mathrm{D}_{2} \mathrm{O}$ solution.

(a) $\gamma$-Tocopherol

\begin{tabular}{lllllll}
\hline & Blank & \multicolumn{1}{c}{$\alpha$-Toc } & \multicolumn{1}{c}{ AO-1 } & AO-2 & AO-3 & AO-4 \\
\hline Concn (M) & 0 & $5.19 \times 10^{-4}$ & $2.22 \times 10^{-4}$ & $4.44 \times 10^{-4}$ & $7.77 \times 10^{-4}$ & $1.11 \times 10^{-3}$ \\
$S_{\text {AO }}\left(\mathrm{s}^{-1}\right)$ & 0.0255 & 0.0088 & 0.0148 & 0.0112 & 0.0083 & 0.0061 \\
$t_{1 / 2}(\min )$ & 26.6 & 71.0 & 39.6 & 51.9 & 77.4 & 94.0 \\
Relative SOAC & - & - & 0.685 & 0.666 & 0.764 & 0.710 \\
value & & & & & & $($ av. 0.706$)$ \\
\hline
\end{tabular}

(b) Ferulic acid

\begin{tabular}{lllllll}
\hline & \multicolumn{1}{c}{ Blank } & \multicolumn{1}{c}{$\alpha$-Toc } & \multicolumn{1}{c}{ AO-1 } & \multicolumn{1}{c}{ AO-2 } & AO-3 & AO-4 \\
\hline Concn (M) & 0 & $5.04 \times 10^{-4}$ & $2.42 \times 10^{-2}$ & $4.85 \times 10^{-2}$ & $9.69 \times 10^{-2}$ & $1.21 \times 10^{-1}$ \\
$S_{\text {AO }}\left(\mathrm{s}^{-1}\right)$ & 0.0360 & 0.0124 & 0.0282 & 0.0243 & 0.0191 & 0.0170 \\
$t_{1 / 2}(\min )$ & 26.4 & 60.5 & 30.6 & 33.6 & 40.6 & 44.5 \\
Relative SOAC & - & - & 0.00257 & 0.00219 & 0.00217 & 0.00221 \\
value & & & & & & $($ av. 0.00228$)$ \\
\hline
\end{tabular}

(c) Epicatechin

\begin{tabular}{lllllll}
\hline & Blank & \multicolumn{1}{c}{$\alpha$-Toc } & \multicolumn{1}{c}{ AO-1 } & \multicolumn{1}{c}{ AO-2 } & AO-3 & AO-4 \\
\hline Concn (M) & 0 & $5.28 \times 10^{-4}$ & $4.63 \times 10^{-3}$ & $6.94 \times 10^{-3}$ & $9.25 \times 10^{-3}$ & $1.16 \times 10^{-2}$ \\
$S_{\text {AO }}\left(\mathrm{s}^{-1}\right)$ & 0.0315 & 0.0113 & 0.0140 & 0.0116 & 0.0094 & 0.0074 \\
$t_{1 / 2}(\min )$ & 23.0 & 62.8 & 48.7 & 61.4 & 73.5 & 94.2 \\
Relative SOAC & - & - & 0.0736 & 0.0734 & 0.0724 & 0.0814 \\
value & & & & & & $($ av. 0.0752$)$ \\
\hline
\end{tabular}

(d) Epicatechin gallate

\begin{tabular}{lllllll}
\hline & \multicolumn{1}{c}{ Blank } & \multicolumn{1}{c}{$\alpha$-Toc } & \multicolumn{1}{c}{ AO-1 } & \multicolumn{1}{c}{ AO-2 } & AO-3 & AO-4 \\
\hline Concn $(\mathrm{M})$ & 0 & $4.99 \times 10^{-4}$ & $9.11 \times 10^{-4}$ & $1.37 \times 10^{-3}$ & $2.73 \times 10^{-3}$ & $4.55 \times 10^{-3}$ \\
$S_{\text {AO }}\left(\mathrm{s}^{-1}\right)$ & 0.0509 & 0.0169 & 0.0431 & 0.0404 & 0.0348 & 0.0290 \\
$t_{1 / 2}(\min )$ & 14.7 & 38.6 & 17.0 & 17.8 & 19.5 & 23.1 \\
$\begin{array}{l}\text { Relative SOAC } \\
\text { value }\end{array}$ & - & - & 0.0516 & 0.0472 & 0.0367 & 0.0383 \\
& & & & & & $($ av. 0.0375$)$ \\
\hline
\end{tabular}

of the AOs. For instance, in the cases of EGC, 4-MC, and 4-MG, similar SOAC values were obtained for four concentrations of the AOs, being independent on the concentrations of the AOs. The rate constants $\left(k_{Q}{ }^{A O}(S)\right.$ and $\left.k_{0}{ }^{A O}\left(t_{1 / 2}\right)\right)$ and the minimum and maximum SOAC values (and average SOAC values) obtained were listed in Tables 2 and 3 (33).

In the case of ECG, notable decrease of the SOAC values $(0.0516,0.0472,0.0367$, and 0.0383) (see Table $3(\mathrm{~d})$ ) was observed with increasing concentrations of ECG $\left(9.11 \times 10^{-4}, 1.37 \times 10^{-3}, 2.73 \times 10^{-3}\right.$, and $4.55 \times 10^{-3} \mathrm{M}$, respectively), because, if the concentrations of ECG are low $\left([\mathrm{ECG}]=9.11 \times 10^{-4}\right.$ and $\left.1.37 \times 10^{-3} \mathrm{M}\right)$, the differences between the half-lives for ECG and blank $\left(t_{1 / 2}{ }^{\mathrm{ECG}}-t_{1 / 2}{ }^{\text {blank }}\right)$ are smaller than $\sim 5 \mathrm{~min}$ and, thus, we cannot obtain reliable SOAC values. At higher concentrations of ECG $\left([\mathrm{ECG}]=2.73 \times 10^{-3}\right.$ and $\left.4.55 \times 10^{-3} \mathrm{M}\right)$, similar SOAC values $(0.0367$ and 0.0383, av 0.0375) were obtained. The SOAC values obtained for $t_{1 / 2}{ }^{\mathrm{ECG}}-t_{1 / 2}{ }^{\text {blank }}>\sim 5 \mathrm{~min}$ agree well with the relative rate constant $\left(k_{\mathrm{Q}}{ }^{\mathrm{AO}}(S) / k_{\mathrm{Q}}{ }^{\alpha \text {-Toc }}(S)=0.0377\right)$, as expected from Eq. (2) (see Table 3(d)). Similar results were obtained for EGCG. The SOAC values of EGCG obtained for $t_{1 / 2}{ }^{\mathrm{EGCG}}-t_{1 / 2}{ }^{\text {blank }}>\sim 5 \mathrm{~min}$ are listed in Table 2.

As described above, measurements of the $k_{0}(S)$ values were performed for 16 phenolic and polyphenolic AOs in mixed solvent (Table 2). As reported in a previous study (33), the values of $\log k_{Q}(S)$ were plotted against oxidation potential $\left(E_{\mathrm{P}}\right)$ of AOs. Log $k_{\mathrm{Q}}(S)$ of AOs correlates well with $E_{\mathrm{P}}$ with a slope of $-(5.7 \pm 0.3) \mathrm{V}^{-1}$ (correlation coefficient $=-0.98)$. The AOs that have smaller $E_{\mathrm{P}}$ values show higher reactivities (that is, higher ${ }^{1} \mathrm{O}_{2}$-quenching activities). The chroman ring of trolox 
Table 4. UV-vis absorption maxima $\left(\lambda_{\max }{ }^{i}(i=1-5)\right)$ and molar extinction coefficients $\left(\varepsilon_{i}(i=1-5)\right)$ of the carotenoids $\mathbf{1}-\mathbf{8}$ and used compounds in ethanol/chloroform/ $\mathrm{D}_{2} \mathrm{O}(50: 50: 1, \mathrm{v} / \mathrm{v} / \mathrm{v})$ solution.

\begin{tabular}{|c|c|c|c|c|}
\hline Molecules & $\begin{array}{c}\lambda_{\max }{ }^{1} / \mathrm{nm} \\
\left(\varepsilon_{1} / \mathrm{M}^{-1} \mathrm{~cm}^{-1}\right)\end{array}$ & $\begin{array}{c}\lambda_{\max }^{2} / \mathrm{nm} \\
\left(\varepsilon_{2} / \mathrm{M}^{-1} \mathrm{~cm}^{-1}\right)\end{array}$ & $\begin{array}{l}\lambda_{\max }{ }^{3} \text { and } \lambda_{\max }{ }^{4} / \mathrm{nm} \\
\left(\varepsilon_{3} \text { and } \varepsilon_{4} / \mathrm{M}^{-1} \mathrm{~cm}^{-1}\right)\end{array}$ & $\begin{array}{c}\lambda^{5} / \mathrm{nm} \\
\left(\varepsilon_{5} / \mathrm{M}^{-1} \mathrm{~cm}^{-1}\right)\end{array}$ \\
\hline Lycopene & 479 & 511 & 452 (110000) & 413 \\
\hline$($ Lyc 1) & $(160000)^{\mathrm{a}}$ & (140000) & $298(40500)$ & $(40900)^{\mathrm{a}}$ \\
\hline $\begin{array}{l}\text { Astaxanthin } \\
\text { (Ast 2) }\end{array}$ & $\begin{array}{c}486 \\
(124000)^{\mathrm{a}}\end{array}$ & & & $\begin{array}{c}413 \\
(35600)^{\mathrm{a}}\end{array}$ \\
\hline $\begin{array}{l}\beta \text {-Carotene } \\
(\beta \text {-Car 3) }\end{array}$ & $\begin{array}{c}459 \\
(133000)^{\mathrm{a}}\end{array}$ & $\begin{array}{c}485 \\
(117000)\end{array}$ & $\begin{array}{c}277 \\
(21500)\end{array}$ & $\begin{array}{c}413 \\
(56800)^{\mathrm{a}}\end{array}$ \\
\hline $\begin{array}{l}\text { Capsanthin } \\
\text { (Cap 4) }\end{array}$ & $\begin{array}{c}481 \\
(106000)^{\mathrm{a}}\end{array}$ & & $\begin{array}{c}292 \\
(18700)\end{array}$ & $\begin{array}{c}413 \\
(32900)^{\mathrm{a}}\end{array}$ \\
\hline $\begin{array}{l}\text { Zeaxanthin } \\
\quad \text { (Zea 5) }\end{array}$ & $\begin{array}{c}459 \\
(129000)^{\mathrm{a}}\end{array}$ & $\begin{array}{c}485 \\
(114000)\end{array}$ & $\begin{array}{c}278 \\
(21900)\end{array}$ & $\begin{array}{c}413 \\
(55200)^{\mathrm{a}}\end{array}$ \\
\hline $\begin{array}{r}\alpha \text {-Carotene } \\
(\alpha \text {-Car } \mathbf{6})\end{array}$ & $\begin{array}{c}453 \\
(138000)^{\mathrm{a}}\end{array}$ & $\begin{array}{c}481 \\
(123000)\end{array}$ & $\begin{array}{c}270 \\
(24000)\end{array}$ & $\begin{array}{c}413 \\
(64700)^{\mathrm{a}}\end{array}$ \\
\hline $\begin{array}{l}\text { Lutein } \\
\qquad(\text { Lut 7) }\end{array}$ & $\begin{array}{c}452 \\
(126000)^{\mathrm{a}}\end{array}$ & $\begin{array}{c}480 \\
(113000)\end{array}$ & $\begin{array}{c}269 \\
(26000)\end{array}$ & $\begin{array}{c}413 \\
(61100)^{\mathrm{a}}\end{array}$ \\
\hline $\begin{array}{l}\beta \text {-Cryptoxanthin } \\
(\text { Crp 8) }\end{array}$ & $\begin{array}{c}459 \\
(95100)^{\mathrm{a}}\end{array}$ & $\begin{array}{c}485 \\
(82400)\end{array}$ & $\begin{array}{c}262 \\
(22700)\end{array}$ & $\begin{array}{c}413 \\
(43500)^{\mathrm{a}}\end{array}$ \\
\hline $\begin{array}{l}\alpha \text {-Tocopherol } \\
(\alpha \text {-Toc })\end{array}$ & $\begin{array}{c}237 \\
(1930)\end{array}$ & $\begin{array}{c}293 \\
(2980)^{\mathrm{a}}\end{array}$ & & \\
\hline $\begin{array}{l}\text { Endoperoxide } \\
\text { (EP) }\end{array}$ & $\begin{array}{c}236 \\
(1630)\end{array}$ & & & \\
\hline EP-precursor & $\begin{array}{c}290 \\
(7670)\end{array}$ & $\begin{array}{c}281 \\
(6350)\end{array}$ & $\begin{array}{c}239 \\
(9130)\end{array}$ & \\
\hline DPBF & $\begin{array}{c}413 \\
(20900)^{\mathrm{b}}\end{array}$ & $\begin{array}{c}315 \\
(7950)\end{array}$ & $\begin{array}{c}264 \\
(25600)\end{array}$ & $\begin{array}{c}413 \\
(20900)^{b}\end{array}$ \\
\hline
\end{tabular}

a Average of values obtained by measurements repeated three to five times. The values of $\varepsilon$ were not varied by the dilution of the solution, indicating that the carotenoids 1-8 are completely dissolved in the solution. Experimental errors in the values of $\varepsilon$ were estimated to be $5 \%$.

${ }^{\mathrm{b}}$ Average of values obtained by measurements repeated five times.

is substituted by an electron withdrawing $\mathrm{COOH}$ group, and thus trolox shows higher oxidation potential $\left(E_{\mathrm{P}}\right)$ (i.e. slower ${ }^{1} \mathrm{O}_{2}$-quenching reaction rate, $k_{Q}(S)$ ).

\section{6. ${ }^{1} \mathrm{O}_{2}$-Quenching Rates $\left(k_{Q}(S)\right.$ and $\left.k_{Q}\left(t_{1 / 2}\right)\right)$ and SOAC Values for 8 Carotenoids}

6-1. UV-vis absorption spectra of 8 representative carotenoids

Measurements of UV-vis absorption spectra have been performed for many Cars in organic solvents $(30,45)$. Although the values of the wavelengths of absorption maxima $\left(\lambda_{\max }\right)$ were reported for many Cars, the Cars whose molar extinction coefficients $\left(\varepsilon_{\max }\right)$ were determined are very limited, because solubility of Cars is generally low (or very low) in organic solvents and varies remarkably depending on the kinds of solvent. Furthermore, commercially-available Cars are very expensive.

Therefore, measurements of UV-vis absorption spectra of 8 Cars were performed in mixed solvent, and the correct $\lambda_{\max }$ and $\varepsilon_{\max }$ values were determined by repeating the measurements three to five times as reported (31). The average values reported are listed in Table 4. UV-vis absorption spectrum for $\beta$-Car is shown in Fig. $2 \mathrm{~A}$. Further, $\lambda_{\max }$ and $\varepsilon_{\max }$ values of $\alpha$-Toc, EP, EP-precursor, and DPBF used for the measurement were also listed in Table 4, together with those for Cars. As listed in Table 4, UV-vis absorptions of 8 Cars overlap to that of DPBF at $413 \mathrm{~nm}$.

6.2. Measurement of $k_{Q}$ and SOAC values of 8 representative carotenoids

Measurements of $k_{Q}(S), k_{Q}\left(t_{1 / 2}\right)$, and SOAC values were performed for 8 Cars (Table 1) $(31,32)$. Figure 2 shows an example of the reaction between $\beta$-Car and ${ }^{1} \mathrm{O}_{2}$ in mixed solvent. Decay curves of the absorbance of DPBF at $413 \mathrm{~nm}$ produced by the reaction with ${ }^{1} \mathrm{O}_{2}$ for $\beta$-Car are shown in Fig. 2B. As $\beta$-Car shows an absorption at $413 \mathrm{~nm}$ (Fig. 2A and Table 4), baseline corrections were performed by using an absorbance at $413 \mathrm{~nm}$ of UV-vis absorption spectrum in Fig. 2A. The decay curves corrected are shown in Fig. 2C. In [Absorbance] vs time plots are shown in Fig. 2D, indicating that the decay of DPBF for $\beta$-Car follows first-order kinetics at $\sim 10<t<\sim 50$ min (31). Plots of $S_{\text {blank }} / S_{\beta \text {-Car }}$ and $t_{1 / 2} \beta$-Toc/ $t_{1 / 2}{ }^{\text {blank }}$ vs $[\beta$-Car] is shown in Fig. $2 \mathrm{E}$ and $2 \mathrm{~F}$, respectively. The $k_{Q}{ }^{\beta-T_{0}}(S)$ and $k_{Q}{ }^{\beta-T_{0 c}}\left(t_{1 / 2}\right)$ values obtained by using Eqs. (3) and (4) are $1.04 \times 10^{10}$ and $1.01 \times 10^{10} \mathrm{M}^{-1} \mathrm{~s}^{-1}$, respectively, showing good agreement with each other. Similar measurements were performed for 8 Cars. The values obtained for 8 Cars are listed in Table 1 , together with that for $\alpha$-Toc. The $k_{\mathrm{Q}}{ }^{\mathrm{Car}}$ values obtained for 8 Cars 
A

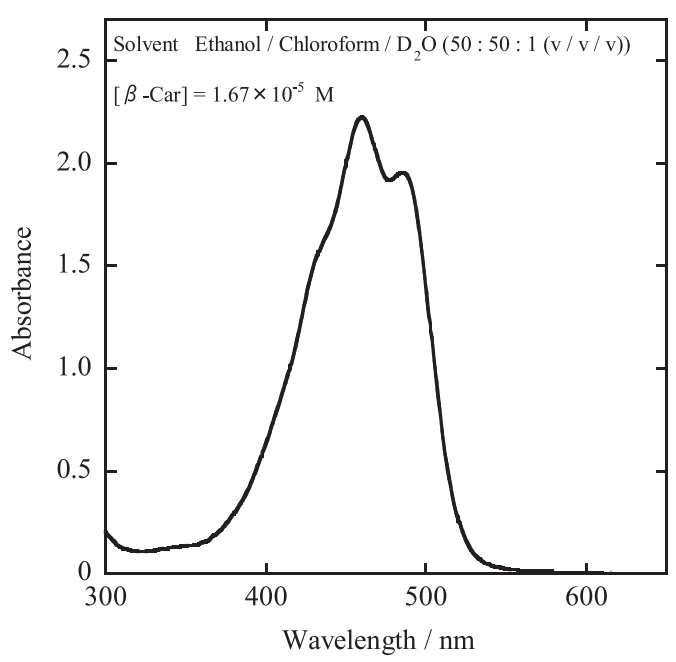

$\mathrm{C}$

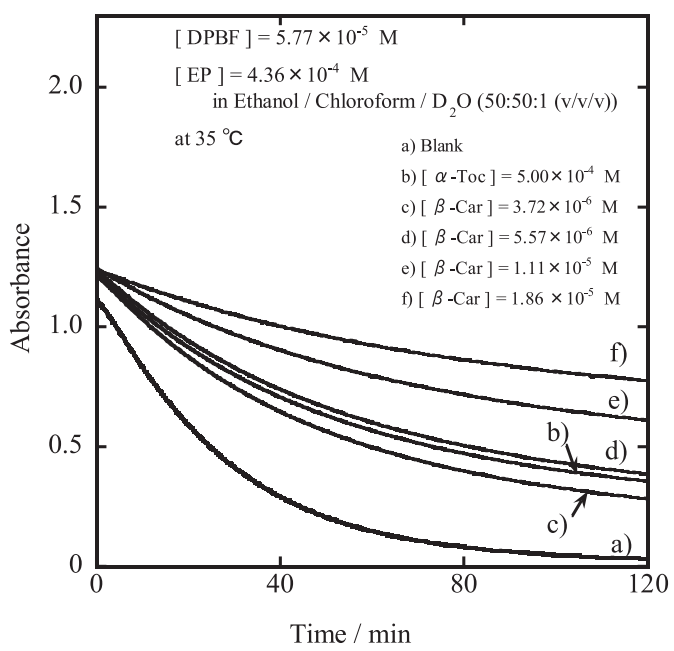

$\mathrm{E}$

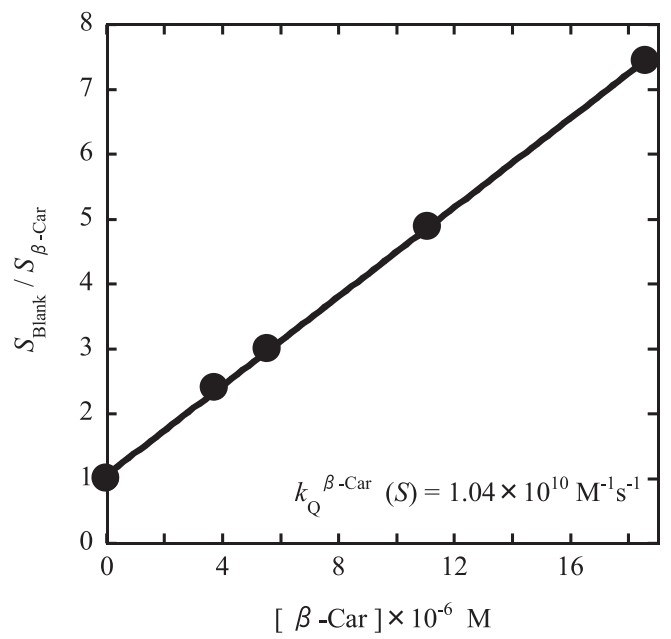

$\mathrm{B}$

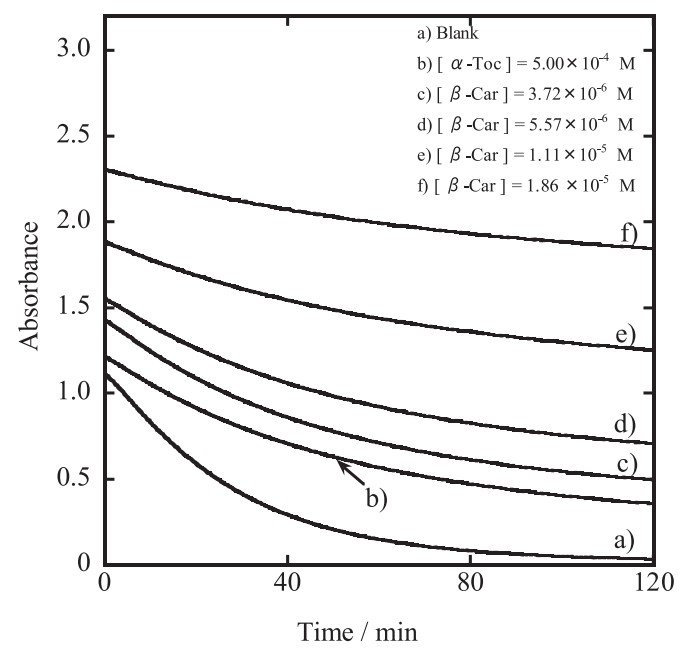

$\mathrm{D}$

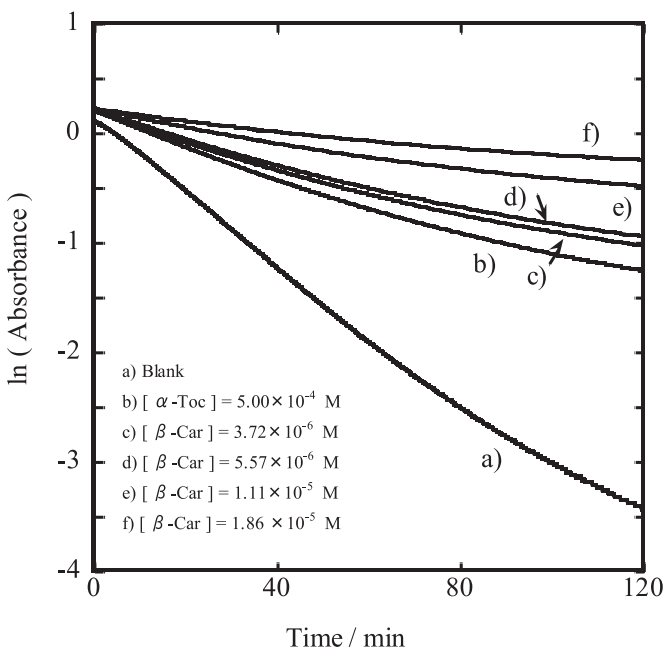

$\mathrm{F}$

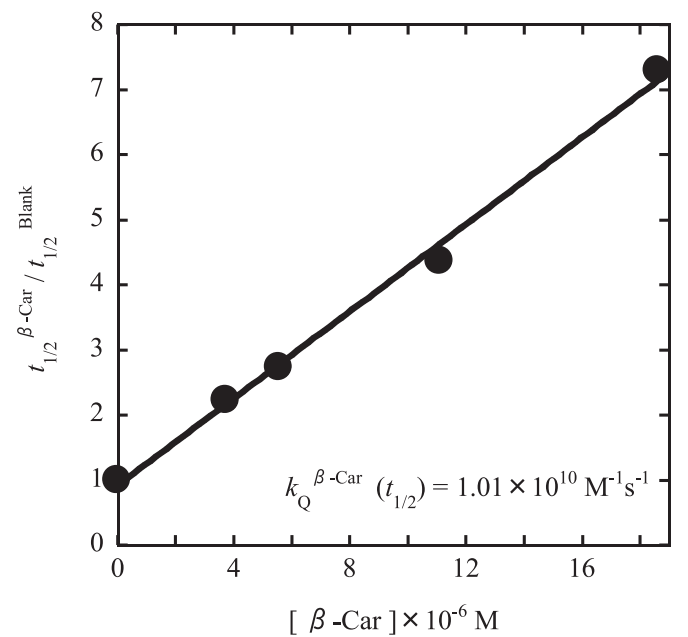

Fig. 2. (A) Absorption spectrum of $\beta$-carotene in ethanol/chloroform $/ \mathrm{D}_{2} \mathrm{O}$. (B) Change in absorbance of DPBF at $413 \mathrm{~nm}$ during the reaction of DPBF with ${ }^{1} \mathrm{O}_{2}$ in the absence and presence of sample ( $\alpha$-tocopherol and $\beta$-carotene) in ethanol : chloroform : $\mathrm{D}_{2} \mathrm{O}$ at $35^{\circ} \mathrm{C}$. $[\mathrm{DPBF}]_{t=0}=5.77 \times 10^{-5} \mathrm{M}$ and $[\mathrm{EP}]_{t=0}=4.36 \times 10^{-4} \mathrm{M}$. The values of $[\alpha-\mathrm{Toc}]_{t=0}$ and $[\beta \text {-Car }]_{t=0}$ are shown in panel C. (C) Change in absorbance of DPBF, where the correction of baseline due to $\beta$-carotene

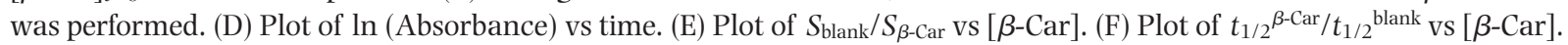


A

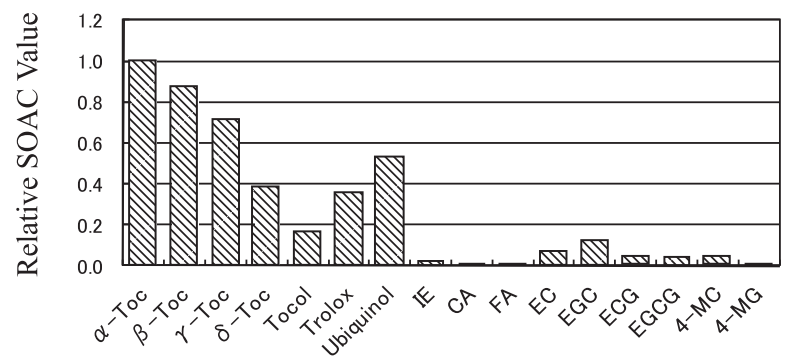

B

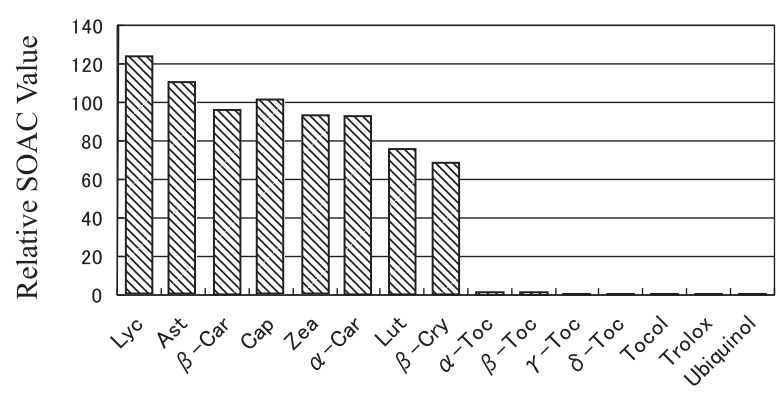

Fig. 3. Comparison of the relative SOAC values for (A) tocopherol derivatives, ubiquinol-10, caffeic acids, catechins, and vitamin C and for (B) carotenoids, tocopherol derivatives, and ubiquinol-10 in ethanol/chloroform $/ \mathrm{D}_{2} \mathrm{O}$ solution.

are about two orders of magnitude larger than that for $\alpha$-Toc.

As described above, ${ }^{1} \mathrm{O}_{2}$-quenching rates $\left(k_{0}{ }^{\mathrm{AO}}(S)\right.$ and $\left.k_{0}{ }^{\mathrm{AO}}\left(t_{1 / 2}\right)\right)$ and the relative SOAC values were measured for 8 Cars and many phenolic AOs in mixed solvent at $35^{\circ} \mathrm{C}$ using UV-vis spectrophotometry (31-33). As listed in Tables 1 and 2, a fair agreement between the relative rate constant $\left(k_{Q}{ }^{\mathrm{AO}}(S) / k_{Q}{ }^{\alpha-\operatorname{Toc}}(S)\right)$ and the average SOAC value was obtained for many phenolic AOs and 8 Cars. The result indicates that the method of the analysis used for estimating the SOAC value is reasonable. From the results, it has been clarified that the SOAC method is useful to evaluate the ${ }^{1} \mathrm{O}_{2}$-quenching activity of lipophilic and hydrophilic antioxidants having five orders of magnitude different rate constants from $1.40 \times 10^{10} \mathrm{M}^{-1} \mathrm{~s}^{-1}$ for Lyc to $2.71 \times 10^{5}$ for FA (see Tables 1 and 2). The relative SOAC values obtained for 8 Cars and many phenolic AOs in mixed solvent are shown as a bar graph in Fig. 3 (33).

\section{Application of SOAC Assay Method to 23 Kinds of Food Extracts}

7.1. Measurements of the $k_{Q}$ and SOAC values for tomato extracts

Application of SOAC method to 23 kinds of vegetable and fruit extracts was performed $(31,32,35)$. All vegetable and fruit samples were purchased at a local market. Basically, edible portions of foods were used for the extraction. In the cases of onion, satsuma mandarin, orange melon, persimmon, banana, and green melon, the part of peel was took off before freeze-drying, and the remaining part was used for extraction. The measurement of relative SOAC value was performed in the following way; for example, the tomato extract prepared from $1.00 \mathrm{~g}$ of freeze-dried powder was dissolved in $25 \mathrm{~mL}$ of ethanol/chloroform $/ \mathrm{D}_{2} \mathrm{O} \quad(50: 50: 1$, $\mathrm{v} / \mathrm{v} / \mathrm{v}$ ) solution. From this solution, four concentrations of tomato-1 were prepared (see Supplemental Online Material, Fig. S1B).

The tomato extract shows UV-vis absorption spectrum at $400-550 \mathrm{~nm}$, suggesting that high concentrations of carotenoids are included in tomato (Supplemental Online Material, Fig. S1A) $(18,32,35)$. Therefore, analysis of the $k_{Q}{ }^{\text {Tomato }}(S)$ and $k_{Q}{ }^{\text {Tomato }}\left(t_{1 / 2}\right)$ values for tomato extract was performed, following the method similar to that of $\beta$-Car (see Fig. 2), as described below. Decay curves of the absorbance of DPBF due to the reaction with ${ }^{1} \mathrm{O}_{2}$ for tomato extract are shown in Fig. S1B. Base line corrections were performed by using an absorbance at $413 \mathrm{~nm}$ of UV-vis absorption spectrum in Fig. S1A, and the decay curves corrected are shown in Fig. S1C. In [Absorbance] vs time plots are shown in Fig. S1D, indicating that the decay of DPBF for tomato extract also follows first-order kinetics at $\sim 5<t<\sim 60 \mathrm{~min}$.

$S^{\text {blank }} / S^{\text {Tomato }}$ and $t_{1 / 2}{ }^{\text {Tomato }} / t_{1 / 2}$ blank $v s$ [Tomato] (by g/L unit) plots are shown in Figs. S1E and S1F, respectively. Both the $S^{\text {blank }} / S^{\text {Tomato }}$ and $t_{1 / 2}{ }^{\text {Tomato }} / t_{1 / 2}$ blank values increase linearly with increasing the concentration of tomato extract ([Tomato]), and the plots show similar slopes, that is, similar rate constants $\left(k_{Q}{ }^{\text {Tomato }}(S)\right.$ and $\left.k_{Q}{ }^{\text {Tomato }}\left(t_{1 / 2}\right)\right)$, where the unit of $k_{Q}^{\text {Tomato }}$ is $\mathrm{L} \mathrm{g}^{-1} \mathrm{~s}^{-1}$. The $k_{Q}{ }^{\text {Tomato }}(S)$ and $k_{Q}{ }^{\text {Tomato }}\left(t_{1 / 2}\right)$ values obtained are $1.69 \times 10^{4}$ and $1.53 \times 10^{4} \mathrm{~L} \mathrm{~g}^{-1} \mathrm{~s}^{-1}$, respectively (32). The linear dependence of $S^{\text {blank }} / S^{\text {Tomato }}$ and $t_{1 / 2}$ Tomato/ $t_{1 / 2}$ blank values on [Tomato] suggests that the effects of the interactions between Cars included in tomato (mainly Lyc and $\beta$-Car $(18,31,32,35)$ ) and among the Cars and many compounds included in solution are negligible.

7.2. Measurements of the $k_{Q}$ and SOAC values for 23 kinds of food extracts

Similar measurements of the ${ }^{1} \mathrm{O}_{2}$-quenching rates $\left(k_{Q}(S)\right.$ and $\left.k_{Q}\left(t_{1 / 2}\right)\right)$ were performed for 23 kinds of food extracts (see Table 5) (35). For example, tomato-1 and -2 extracts were prepared by repeating extraction twice from freeze-dried powder sample. The $k_{Q}{ }^{\text {food }}(S)$ and $k_{0}{ }^{\text {food }}\left(t_{1 / 2}\right)$ values obtained for food- 1 and food- 2 are similar to each other, respectively, as listed in Table 5. The $k_{Q}{ }^{\text {food }}(S)$ values of food extracts varied notably depending on the kinds of food ones, as expected. The $k_{0}{ }_{0}^{\text {food }}(S)$ value $\left(3.18 \times 10^{4} \mathrm{~L} \mathrm{~g}^{-1} \mathrm{~s}^{-1}\right)$ of tomato- 1 was 205 times larger than that $\left(1.55 \times 10^{2} \mathrm{~L} \mathrm{~g}^{-1} \mathrm{~s}^{-1}\right)$ of green melon-1.

As listed in Table $5 \mathrm{~A}$ and $5 \mathrm{~B}$, a fair agreement between the $k_{Q}{ }^{\text {food }}(S)$ and $k_{Q}$ food $\left(t_{1 / 2}\right)$ values was observed for 14 kinds of vegetable extracts among 16 vegetable ones and all 7 kinds of fruits. Agreement was not sufficient only in the cases of eggplant-1, daikon radish-1 and -2 , having slow ${ }^{1} \mathrm{O}_{2}$-quenching rates (that is, low ${ }^{1} \mathrm{O}_{2}$-quenching activity). However, the result of the present investigation indicates that measurements of the rate constants $\left(k_{Q}{ }^{\text {food }}(S)\right.$ and $\left.k_{Q}{ }^{\text {food }}\left(t_{1 / 2}\right)\right)$ based on the analyses of the first-order rate constant $(S)$ and the half-life $\left(t_{1 / 2}\right)$ of the decay curve of DPBF, respectively, 
Table 5. $\quad k_{Q}{ }_{0}^{\text {food }}(S)$ and $k_{Q}{ }^{\text {food }}\left(t_{1 / 2}\right)$ values observed for (A) 16 vegetable and (B) 7 fruit extracts in ethanol $/$ chloroform $/ \mathrm{D}_{2} \mathrm{O}$ solution at $35.0^{\circ} \mathrm{C}$, relative rate constants $\left(k_{Q}{ }^{\text {food }}(S) / k_{Q}{ }^{\alpha-T o c}(S)\right)$, relative SOAC values, $k_{Q}{ }^{\text {food }}(S)$ values calculated, and ratio ((B)/(A)).

(A) 16 Kinds of vegetable extracts

\begin{tabular}{|c|c|c|c|c|c|c|}
\hline Vegetable extract & $\begin{array}{c}k_{Q}^{\text {food }}(S) \\
(\text { Obsd.) }(A) \\
/ \mathrm{L} \mathrm{g}^{-1} \mathrm{~s}^{-1}\end{array}$ & $\begin{array}{c}k_{Q}{ }^{\text {food }}\left(t_{1 / 2}\right) \\
/ \mathrm{L} \mathrm{g}^{-1} \mathrm{~s}^{-1}\end{array}$ & $\begin{array}{l}k_{Q}{ }^{\text {food }}(S) / \\
k_{Q_{Q}}{ }^{\alpha-\operatorname{Toc}}(S)\end{array}$ & $\begin{array}{c}\text { Relative SOAC } \\
\text { value }\end{array}$ & $\begin{array}{c}k_{\mathrm{Q}}^{\text {food }}(S) \\
\text { (Calcd.) (B) } \\
/ \mathrm{L} \mathrm{g}^{-1} \mathrm{~S}^{-1}\end{array}$ & $\begin{array}{l}\text { Ratio } \\
\text { (B)/(A) }\end{array}$ \\
\hline$\alpha$-Tocopherol $^{\mathrm{a}}$ & $3.04 \times 10^{5}$ & $3.00 \times 10^{5}$ & 1.00 & 1.00 & - & - \\
\hline Tomato-1 & $3.18 \times 10^{4}$ & $3.05 \times 10^{4}$ & 0.1045 & av $0.115^{b}$ & $2.53 \times 10^{4}$ & 0.796 \\
\hline Tomato-2 & $3.16 \times 10^{4}$ & $2.88 \times 10^{4}$ & 0.1041 & av 0.132 & $2.79 \times 10^{4}$ & 0.883 \\
\hline Tomato (reported) ${ }^{\mathrm{a}}$ & av $1.85 \times 10^{4}$ & av $1.70 \times 10^{4}$ & av 0.0608 & av 0.0727 & $1.41 \times 10^{4}$ & 0.762 \\
\hline Garland chrysanthemum-1 & $2.97 \times 10^{4}$ & $2.82 \times 10^{4}$ & 0.0977 & av 0.105 & $1.80 \times 10^{4}$ & 0.606 \\
\hline Garland chrysanthemum-2 & $2.79 \times 10^{4}$ & $2.61 \times 10^{4}$ & 0.0919 & av 0.103 & $1.78 \times 10^{4}$ & 0.638 \\
\hline Spinach-1 & $2.73 \times 10^{4}$ & $2.70 \times 10^{4}$ & 0.0899 & av 0.157 & $3.55 \times 10^{4}$ & 1.30 \\
\hline Spinach-2 & $2.94 \times 10^{4}$ & $2.81 \times 10^{4}$ & 0.0968 & av 0.131 & $3.51 \times 10^{4}$ & 1.19 \\
\hline Red paprika-1 & $2.37 \times 10^{4}$ & $2.28 \times 10^{4}$ & 0.0778 & av 0.114 & $3.54 \times 10^{4}$ & 1.49 \\
\hline Red paprika-2 & $2.42 \times 10^{4}$ & $2.26 \times 10^{4}$ & 0.0796 & av 0.113 & $3.08 \times 10^{4}$ & 1.27 \\
\hline Red paprika (reported) & av $3.09 \times 10^{4}$ & av $2.86 \times 10^{4}$ & av 0.102 & av 0.117 & $7.88 \times 10^{3}$ & 0.255 \\
\hline Carrot-1 & $1.60 \times 10^{4}$ & $1.46 \times 10^{4}$ & 0.0528 & av 0.0614 & $1.67 \times 10^{4}$ & 1.04 \\
\hline Carrot-2 & $1.63 \times 10^{4}$ & $1.51 \times 10^{4}$ & 0.0537 & av 0.0687 & $1.66 \times 10^{4}$ & 1.02 \\
\hline Carrot $\left(\right.$ reported) ${ }^{\mathrm{a}}$ & av $1.48 \times 10^{4}$ & av $1.25 \times 10^{4}$ & av 0.0486 & av 0.0530 & $1.42 \times 10^{4}$ & 0.959 \\
\hline Chinese leek-1 & $1.38 \times 10^{4}$ & $1.21 \times 10^{4}$ & 0.0454 & av 0.0500 & $1.25 \times 10^{4}$ & 0.906 \\
\hline Chinese leek-2 & $1.47 \times 10^{4}$ & $1.29 \times 10^{4}$ & 0.0483 & av 0.0530 & $1.26 \times 10^{4}$ & 0.857 \\
\hline Pumpkin-1 & $1.39 \times 10^{4}$ & $1.36 \times 10^{4}$ & 0.0458 & av 0.0516 & $5.51 \times 10^{3}$ & 0.396 \\
\hline Pumpkin-2 & $1.16 \times 10^{4}$ & $1.11 \times 10^{4}$ & 0.0380 & av 0.0436 & $5.01 \times 10^{3}$ & 0.433 \\
\hline Cucumber-1 & $5.23 \times 10^{3}$ & $5.14 \times 10^{3}$ & 0.0172 & av 0.0146 & $3.03 \times 10^{3}$ & 0.579 \\
\hline Cucumber-2 & $5.74 \times 10^{3}$ & $5.45 \times 10^{3}$ & 0.0189 & av 0.0143 & $3.02 \times 10^{3}$ & 0.526 \\
\hline Broccoli-1 & $5.17 \times 10^{3}$ & $5.13 \times 10^{3}$ & 0.0170 & av 0.0172 & $2.52 \times 10^{3}$ & 0.487 \\
\hline Broccoli-2 & $4.68 \times 10^{3}$ & $4.39 \times 10^{3}$ & 0.0154 & av 0.0183 & $3.65 \times 10^{3}$ & 0.780 \\
\hline Green pepper-1 & $4.72 \times 10^{3}$ & $4.58 \times 10^{3}$ & 0.0155 & av 0.0151 & $3.48 \times 10^{3}$ & 0.737 \\
\hline Green pepper-2 & $3.41 \times 10^{3}$ & $3.62 \times 10^{3}$ & 0.0112 & av 0.0108 & $3.90 \times 10^{3}$ & 1.14 \\
\hline Okra-1 & $3.09 \times 10^{3}$ & $2.94 \times 10^{3}$ & 0.0102 & av 0.0122 & $9.66 \times 10^{2}$ & 0.313 \\
\hline Okra-2 & $4.07 \times 10^{3}$ & $3.94 \times 10^{3}$ & 0.0134 & av 0.0173 & $9.45 \times 10^{2}$ & 0.232 \\
\hline Eggplant-1 & $8.09 \times 10^{2}$ & $1.29 \times 10^{3}$ & 0.0027 & av 0.0058 & $4.47 \times 10^{2}$ & 0.553 \\
\hline Eggplant-2 & $7.61 \times 10^{2}$ & $6.83 \times 10^{2}$ & 0.0025 & av 0.0030 & $4.77 \times 10^{2}$ & 0.627 \\
\hline Cabbage-1 & $5.93 \times 10^{2}$ & $5.50 \times 10^{2}$ & 0.0020 & av 0.0029 & $1.28 \times 10^{2}$ & 0.216 \\
\hline Cabbage-2 & $5.48 \times 10^{2}$ & $5.89 \times 10^{2}$ & 0.0018 & av 0.0032 & $1.30 \times 10^{2}$ & 0.237 \\
\hline Onion-1 & $3.09 \times 10^{2}$ & $3.79 \times 10^{2}$ & 0.0010 & tenta $0.0021^{\mathrm{c}}$ & 0 & 0 \\
\hline Onion-2 & $5.88 \times 10^{2}$ & $5.10 \times 10^{2}$ & 0.0019 & av 0.0036 & 0 & 0 \\
\hline Sweet potato-1 & $4.65 \times 10^{2}$ & $4.40 \times 10^{2}$ & 0.0015 & av 0.0020 & $5.21 \times 10^{1}$ & 0.112 \\
\hline Sweet potato-2 & $3.83 \times 10^{2}$ & $3.89 \times 10^{2}$ & 0.0013 & tenta 0.0020 & $4.85 \times 10^{1}$ & 0.127 \\
\hline Daikon radish-1 & $2.08 \times 10^{2}$ & $2.74 \times 10^{2}$ & 0.0007 & tenta 0.0013 & $3.02 \times 10^{1}$ & 0.145 \\
\hline Daikon radish-2 & $2.81 \times 10^{2}$ & $3.46 \times 10^{2}$ & 0.0009 & tenta 0.0017 & 8.05 & 0.0286 \\
\hline
\end{tabular}

(B) 7 Kinds of fruit extracts

\begin{tabular}{lcccccc}
\multicolumn{1}{c}{ Fruit extract } & $\begin{array}{c}k_{Q}{ }^{\text {food }}(S) \\
(\text { Obsd. })(A) \\
/ \mathrm{L} \mathrm{g}^{-1} \mathrm{~S}^{-1}\end{array}$ & $\begin{array}{c}k_{\mathrm{Q}}{ }^{\text {food }}\left(t_{1 / 2}\right) \\
/ \mathrm{L} \mathrm{g}^{-1} \mathrm{~s}^{-1}\end{array}$ & $\begin{array}{c}k_{\mathrm{Q}}{ }^{\text {food }}(S) / \\
k_{\mathrm{Q}}{ }^{\alpha-\operatorname{Toc}}(S)\end{array}$ & $\begin{array}{c}\text { Relative SOAC } \\
\text { value }\end{array}$ & $\begin{array}{c}k_{\mathrm{Q}}{ }^{\text {food }}(S) \\
(\mathrm{Calcd})(B) \\
/ \mathrm{L} \mathrm{g}^{-1} \mathrm{~s}^{-1}\end{array}$ & $\begin{array}{c}\text { Ratio } \\
(B) /(A)\end{array}$ \\
\hline Satsuma mandarin-1 & $4.15 \times 10^{3}$ & $4.01 \times 10^{3}$ & 0.0136 & av $0.0197^{\mathrm{b}}$ & $8.16 \times 10^{2}$ & 0.197 \\
Satsuma mandarin-2 & $4.43 \times 10^{3}$ & $4.43 \times 10^{3}$ & 0.0146 & av 0.0192 & $8.42 \times 10^{2}$ & 0.190 \\
Orange melon-1 & $3.49 \times 10^{3}$ & $3.44 \times 10^{3}$ & 0.0115 & av 0.0163 & $3.25 \times 10^{3}$ & 0.931 \\
Orange melon-2 & $3.92 \times 10^{3}$ & $3.69 \times 10^{3}$ & 0.0129 & av 0.0190 & $3.65 \times 10^{3}$ & 0.931 \\
Persimmon-1 & $1.67 \times 10^{3}$ & $1.45 \times 10^{3}$ & 0.0055 & av 0.0079 & $5.10 \times 10^{2}$ & 0.305 \\
Persimmon-2 & $1.83 \times 10^{3}$ & $1.65 \times 10^{3}$ & 0.0060 & av 0.0095 & $7.85 \times 10^{2}$ & 0.429 \\
Banana-1 & $3.99 \times 10^{2}$ & $4.73 \times 10^{2}$ & 0.0013 & tenta $0.0020^{\mathrm{c}}$ & $1.20 \times 10^{2}$ & 0.301 \\
Banana-2 & $4.74 \times 10^{2}$ & $4.74 \times 10^{2}$ & 0.0016 & av 0.0020 & $1.46 \times 10^{2}$ & 0.308 \\
Strawberry-1 & $4.26 \times 10^{2}$ & $4.32 \times 10^{2}$ & 0.0014 & tenta 0.0020 & $7.69 \times 10^{1}$ & 0.181 \\
Strawberry-2 & $4.26 \times 10^{2}$ & $4.11 \times 10^{2}$ & 0.0014 & tenta 0.0022 & $6.60 \times 10^{1}$ & 0.155 \\
Apple-1 & $3.76 \times 10^{2}$ & $4.08 \times 10^{2}$ & 0.0012 & tenta 0.0022 & $5.23 \times 10^{1}$ & 0.139 \\
Apple-2 & $4.04 \times 10^{2}$ & $3.99 \times 10^{2}$ & 0.0013 & tenta 0.0021 & $4.63 \times 10^{1}$ & 0.115 \\
Green melon-1 & $1.55 \times 10^{2}$ & $1.70 \times 10^{2}$ & 0.0005 & tenta 0.0009 & $4.29 \times 10^{1}$ & 0.277 \\
Green melon-2 & $2.23 \times 10^{2}$ & $2.41 \times 10^{2}$ & 0.0007 & tenta 0.0012 & $4.45 \times 10^{1}$ & 0.200 \\
\hline
\end{tabular}

${ }^{a}$ See Table 6 in Ref. (32).

${ }^{\mathrm{b}}$ av: average SOAC value (see Ref. (35)).

${ }^{\mathrm{c}}$ tenta: tentatively determined SOAC value (see Ref. (35)). 

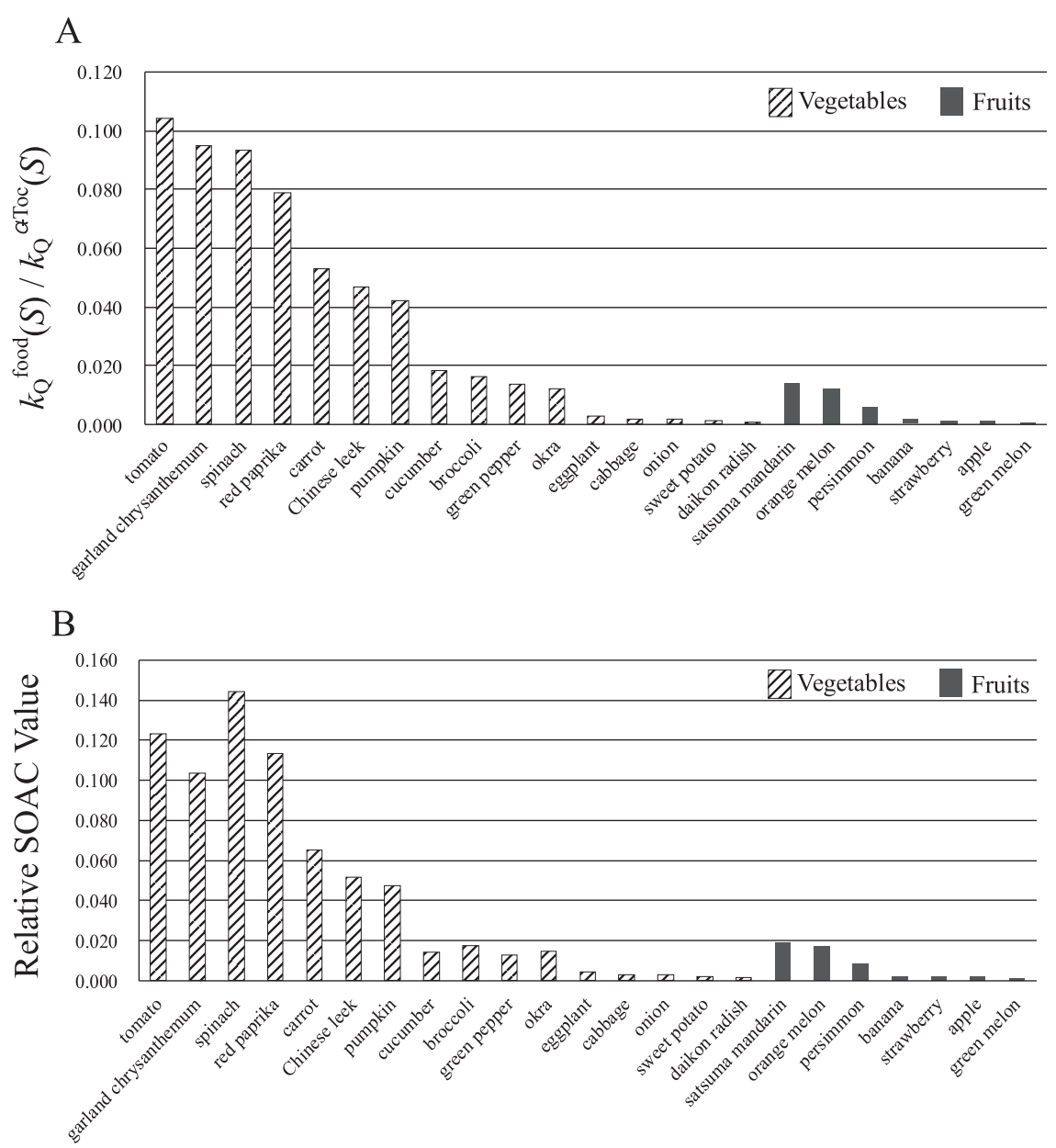

Fig. 4. Comparison of (A) the relative rate constants $\left(k_{Q}{ }^{\text {food }}(S) / k_{Q}{ }^{\alpha-T o c}(S)\right)$ and (B) the relative SOAC values for 16 vegetable and 7 fruit extracts in ethanol/chloroform/ $\mathrm{D}_{2} \mathrm{O}$ solution.

are applicable to general food extracts having more than two orders of magnitude different ${ }^{1} \mathrm{O}_{2}$-quenching rates. As expected from Eq. (2), a fair agreement between the relative rate constant $\left(k_{Q}\right.$ food $\left.(S) / k_{Q}{ }^{\alpha-T o c}(S)\right)$ and the average SOAC value was obtained for many food extracts (Table 5). Average values of the relative rate constants $\left(k_{Q}{ }^{\text {food }}(S) / k_{Q}{ }^{\alpha-T o c}(S)\right)$ obtained for 16 vegetable and 7 fruit extracts in mixed solvent are shown as a bar graph in Fig. 4A (35). The relative SOAC values for 16 vegetable and 7 fruit extracts are also shown in Fig. 4B.

7.3. Comparison between $k_{Q}^{\text {food }}(S)$ (Obsd.) and $k_{Q}^{\text {food }}(S)$ (Calcd.) values for 23 kinds of food extracts

It is well known that various AOs coexist in foods and plants $(16-21)$. As described above, the $k_{0}{ }^{\text {food }}(S)$ $\left(\mathrm{L} \mathrm{g}^{-1} \mathrm{~s}^{-1}\right)$ values for 23 food extracts were measured by the $S_{\text {blank }} / S_{\text {food }}$ vs [food] (g/L) plot, using Eq. (7) (35).

$S_{\text {blank }} / S_{\text {food }}=1+\left\{k_{Q}{ }^{\text {food }}(S)\right.$ (Obsd.) $[$ food $\left.]\right\} / k_{\mathrm{d}}$

As reported in previous works (22-27, 30-34), $k_{Q}{ }^{\mathrm{Car}}(S)$ values of Cars show 2 to 5 orders of magnitude larger than those $\left(k_{0}{ }^{\text {phenolic } \mathrm{AO}}(S)\right)$ of general phenolic AOs, including tocopherol homologues, ubiquinol-10, catechins, and caffeic acids. The result suggests that the contribution of Cars to the ${ }^{1} \mathrm{O}_{2}$-quenching activity of food extracts is considered to be very important. Therefore, measurements of the concentrations of Cars included in 16 vegetable and 7 fruit extracts were performed using a HPLC technique, according to the method reported in a previous work (18). Analyses of the concentrations were performed for 7 Cars $(\alpha$-Car, $\beta$-Car, Lut, Lyc, Cap, Zea, and $\beta$-Cry). The concentrations of 7 Cars included are summarized in Table S1 (Supplemental Online Material).

As listed in Table S1, 7 Cars (Car-i $(i=1-7)$ ) are included in 22 food extracts except for onion among 23 food extracts. Consequently, the $k_{\mathrm{Q}}{ }^{\text {food }}(S)$ values for 23 food extracts were calculated, using Eq. (8), where the $k_{\mathrm{Q}}{ }^{\mathrm{Car}-\mathrm{i}}(\mathrm{S})\left(\mathrm{L} \mathrm{g}^{-1} \mathrm{~s}^{-1}\right)$ values are the rate constants for 7 Cars in mixed solvent $(31,32)$. [Car-i] (unit: mg/100 g) (Table S1) is the concentration of 7 Cars included in food extracts. The $k_{0}$ food $(S)$ (Calcd.) values calculated for 23 food extracts are listed in Table 5.

$k_{Q}{ }^{\text {food }}(S)($ Calcd. $)=\sum k_{Q}{ }^{\text {Car-i }}(S)[$ Car-i $] / 10^{5}(i=1-7)$

We may expect that the $k_{Q}{ }^{\text {food }}(S)$ (Obsd.) (A) values are larger than the corresponding $k_{Q}{ }^{\text {food }}(S)$ (Calcd.) (B) values, that is, the values of ratio $(\mathrm{B}) /(\mathrm{A})$ in Table 5 are $\leq 1$, because not only 7 Cars, but also the other Cars are included in food extracts (16-18). Many phenolic AOs included in food extracts will also contribute to ${ }^{1} \mathrm{O}_{2}$-quenching. Furthermore, chlorophyll a $\left(\lambda_{\max }=430 \mathrm{~nm}\right)$ is included in green vegetables (35). Chlorophyll a shows higher ${ }^{1} \mathrm{O}_{2}$-quenching rate $\left(k_{\mathrm{Q}}(S)=7.3 \times 10^{8} \mathrm{M}^{-1} \mathrm{~S}^{-1}\right.$ in benzene) than $\alpha$-Toc 
(1.31 $\times 10^{8} \mathrm{M}^{-1} \mathrm{~s}^{-1}$ in mixed solvent), suggesting the contribution of chlorophyll $a$ to the $k_{Q}(S)$ (Obsd.) values of green vegetable extracts (46).

As listed in Table 5, good agreement between observed $k_{Q}{ }^{\text {carrot-1 }}$ and ${ }^{-2}(S)$ values $\left(=1.60 \times 10^{4}\right.$ and $\left.1.63 \times 10^{4} \mathrm{~L} \mathrm{~g}^{-1} \mathrm{~s}^{-1}\right)$ and calculated $\left\{\sum k_{\mathrm{Q}}{ }^{\mathrm{Car}-\mathrm{i}}(S)[\mathrm{Car}-\right.$ i] $\left./ 10^{5}\right\}$ values $\left(=1.67 \times 10^{4}\right.$ and $\left.1.66 \times 10^{4} \mathrm{~L} \mathrm{~g}^{-1} \mathrm{~s}^{-1}\right)$ was obtained for carrot-1 and -2 extracts, respectively (35). The result indicates that the total ${ }^{1} \mathrm{O}_{2}$-quenching activity of carrot- 1 and -2 extracts may be well explained by only considering the contribution of 3 kinds of Cars ( $\alpha$-Car, $\beta$-Car, and Lut) included in carrot extracts. The contribution of the other AOs is small and negligible. Similarly, fair agreement between $k_{0}$ food $(S)$ (Obsd.) (A) and $k_{Q}{ }^{\text {food }}(S)$ (Calcd.) (B) values was obtained for 4 food extracts (tomato, Chinese leek, green pepper, and orange melon), which include comparatively high concentrations of Cars (Table S1).

On the other hand, the $k_{0}$ food $(S)$ (Obsd.) values observed for the other 16 food extracts are larger than the corresponding $k_{0}{ }^{\text {food }}(S)$ (Calcd.) values, as listed in Table 5, indicating that the other AOs included also contribute to the $k_{Q}{ }^{\text {food }}(S)$ (Obsd.) values. In fact, the values of ratio (B)/(A) observed for 5 brightly colored vegetable extracts (garland chrysanthemum, pumpkin, cucumber, broccoli, and eggplant) are $0.70>(\mathrm{B}) /(\mathrm{A})>0.50$. Generally, the values of ratio (B)/(A) observed for 5 vegetable extracts (okra, cabbage, onion, sweet potato, and daikon radish extracts), which include low concentrations of carotenoids and show comparatively small $k_{Q}{ }^{\text {food }}(S)$ (obsd.) values, are $0.313>(\mathrm{B}) /(\mathrm{A}) \geq 0.000$. Similarly, 6 fruit extracts except for orange melon also show small values of ratio $(0.429>(\mathrm{B}) /(\mathrm{A})>0.115)$.

For example, 7 Cars are not included in onion-1 and -2 extracts. However, onion- 1 and -2 extracts show ${ }^{1} \mathrm{O}_{2}$-quenching activities $\left(k_{\mathrm{Q}}{ }^{\text {food }}(S)(\right.$ Obsd. $)=3.09 \times 10^{2}$ and $\left.5.88 \times 10^{2} \mathrm{~L} \mathrm{~g}^{-1} \mathrm{~s}^{-1}\right)$, respectively. Onion includes considerable amounts of quercetin which is well known as a representative flavone derivative (47). The $k_{Q}{ }^{\text {quercetin }}(S)$ (Obsd.) value of quercetin reported is $4.57 \times 10^{8} \mathrm{M}^{-1} \mathrm{~s}^{-1} \quad\left(=1.51 \times 10^{6} \mathrm{~L} \mathrm{~g}^{-1} \mathrm{~s}^{-1}\right.$ in ethanol $)$ (48). Quercetin included in onion will contribute to the above ${ }^{1} \mathrm{O}_{2}$-quenching rate.

On the other hand, in the cases of spinach-1 and -2 and red paprika-1 and -2, the values of the ratio (B)/ (A) are $>1.00$ (see Table 5). As listed in Table S1, the total Car concentrations included in spinach-1 and -2 (197.41 and $195.18 \mathrm{mg} / 100 \mathrm{~g}$ ) and red paprika-1 and $-2(193.68$ and $168.30 \mathrm{mg} / 100 \mathrm{~g})$ are the highest ones among 23 kinds of food extracts studied. The result suggests that the interactions between 7 Cars and among 7 Cars and many molecules included in spinach and red paprika extracts may hinder the determination of correct $k_{\mathrm{O}}(S)$ (Obsd.) values. In fact, the total Car concentration included in red paprika $(40.88 \mathrm{mg} / 100 \mathrm{~g})$ reported in a previous work (32) is much lower than the above values (193.68 and $168.30 \mathrm{mg} / 100 \mathrm{~g}$ ), and the value of the ratio $(\mathrm{B}) /(\mathrm{A})$ reported is 0.255 , as listed in Table 5 . However, the reason is not clear at present. Detailed study will be necessary to clarify the reason why the val- ues of the ratio (B)/(A) obtained for spinach-1 and -2 and red paprika- 1 and -2 are $>1.00$.

\section{Application of SOAC Assay Method to 7 Rice Bran Extracts, 8 Vegetable Oils, and 5 Palm Oils}

Further, measurements of the ${ }^{1} \mathrm{O}_{2}$-quenching rates $\left(k_{Q}(S)\right)$ and the relative SOAC values were performed for 7 rice bran extracts, which contained different concentrations of AOs (such as $\alpha-, \beta-, \gamma$-, and $\delta$-Tocs and -Toc3 s, 3 Cars (Lut, $\beta$-Car, and Zea), and $\gamma$-oryzanol), in ethanol at $35^{\circ} \mathrm{C}$ using UV-vis spectrophotometry (28). The concentrations of 4 Tocs and 4 Toc- 3 s, 3 Cars, and $\gamma$-oryzanol contained in the extracts were determined using HPLC-MS/MS, UV-HPLC, and UV-vis absorption spectroscopy, respectively. Similarly, comparisons of $k_{Q}(S)$ (Obsd.) values with $k_{Q}(S)$ (Calcd.) $\left(=\sum k_{Q}{ }^{\mathrm{AO}-i}(S)\right.$ $\left.[\mathrm{AO}-\mathrm{i}] / 10^{5}\right)$ were performed. The ratios $\left(k_{\mathrm{Q}}(\mathrm{Calcd}) / k_{\mathrm{Q}}\right.$ (Obsd.)) for rice bran extracts $1-7$ varied from 0.562 to 0.971. Similar measurements and analyses were performed for (i) 8 vegetable oils (36) and (ii) 5 palm oil and 1 soybean extracts (34), which contained different concentrations of AOs (such as 4 Tocs, 4 Toc-3s, and Cars). It has been ascertained that the SOAC method developed is applicable to general food extracts to evaluate the ${ }^{1} \mathrm{O}_{2}$-quenching activity, as described above.

\section{Measurements of the $k_{Q}$ and SOAC Values for 8 Vitamin $E$ Homologues and 8 Carotenoids in a Micellar Solution}

Liposome is often used as a model of biomembrane. However, the measurement of $k_{0}{ }^{\mathrm{AO}}$ and SOAC values in liposome solution was difficult, because of low solubility of AOs in liposome solution. Solubility of AOs in an aqueous Triton X-100 micellar solution is higher than those in sodium dodecyl sulfate (SDS) and cetyl trimethyl ammonium bromide (CTAB) micellar solutions. Many kinds AOs (such as carotenoids, vitamin E homologues, and polyphenols) are soluble in a Triton X-100 micellar solution. Therefore, using a Triton X-100 (5.0 wt \%) micellar solution ( $\mathrm{pH} 7.4$ ), the measurements of $k_{\mathrm{Q}}{ }^{\mathrm{AO}}(S)$ and $k_{Q}{ }^{A O}\left(t_{1 / 2}\right)$ and SOAC values were performed for (i) vitamin $\mathrm{E}$ homologues $(\alpha-, \beta-, \gamma-, \delta$-Toc and -Toc-3) and (ii) 8 Cars $(37,38)$.

As reported in a previous work (38), ${ }^{1} \mathrm{O}_{2}$-quenching rate constants $\left(k_{\mathrm{Q}}{ }^{\mathrm{AO}}(S)\right)$ of $\alpha-, \beta-, \gamma-, \delta$-Toc and -Toc-3 decreases in the order of Eq. (9) in mixed solvent and ethanol (Table 6).

$\alpha$-Toc $\sim \alpha$-Toc-3> $\beta$-Toc $\sim \beta$-Toc- $3>\gamma$-Toc $\sim \gamma$-Toc- $3>\delta$ Toc $\sim \delta$-Toc- 3

The $k_{0}{ }^{\mathrm{AO}}$ values of $\alpha-, \beta-, \gamma-$, and $\delta$-Toc- 3 show good agreement with those of the corresponding Toc in ethanol and mixed solvent, indicating that the difference in the alkyl side-chains between Toc and Toc-3 does not give a significant effect on the reaction rates. Similar results were reported by Gruszka et al. (49).

On the other hand, the ${ }^{1} \mathrm{O}_{2}$-quenching activity (i.e. $k_{\mathrm{Q}}{ }^{\mathrm{AO}}(S)$ values) of $\alpha-, \beta-, \gamma-, \delta$-Toc and -Toc-3 decreases in the order of Eq. (10) in a Triton X-100 micellar solution (Table 6) (38).

$\alpha$-Toc- $3>\alpha$-Toc $>\gamma$-Toc- $>\beta-$ Toc- $3>\beta$-Toc $>$ 
Table 6. The $k_{0}{ }^{A O}$ values for vitamin E homologues (AOs) in a Triton X-100 micellar solution, ethanol, and mixed solvent at $35.0^{\circ} \mathrm{C}$, and ratio of the rate constants $\left(k_{Q}(\right.$ micelle $) / k_{Q}(\mathrm{EtOH})$ and $k_{Q}{ }^{A O}$ (micelle) $/ k_{Q}{ }^{A O}$ (mixed solvent)

\begin{tabular}{|c|c|c|c|c|c|}
\hline $\begin{array}{l}\text { Antioxidant } \\
\text { (AO) }\end{array}$ & $\begin{array}{c}k_{\mathrm{O}}^{\mathrm{AO} \text { a }} \\
(\mathrm{pH} 7.4) \\
/ \mathrm{M}^{-1} \mathrm{~S}^{-1} \\
\text { micelle }\end{array}$ & $\begin{array}{c}k_{\mathrm{Q}}^{\mathrm{AO}} \\
/ \mathrm{M}^{-1} \mathrm{~s}^{-1} \\
\mathrm{EtOH}^{\mathrm{b}}\end{array}$ & $\begin{array}{c}k_{\mathrm{Q}}{ }^{\mathrm{AO}}(\text { micelle }) / \\
k_{\mathrm{Q}}{ }^{\mathrm{AO}}(\text { EtOH })\end{array}$ & $\begin{array}{c}k_{Q}{ }^{A O} \\
/ \mathrm{M}^{-1} \mathrm{~s}^{-1} \\
\text { mixed solvent } \mathrm{t}^{\mathrm{b}}\end{array}$ & $\begin{array}{c}k_{Q}{ }^{A O}(\text { micelle }) / \\
\left.k_{Q}^{A O} \text { (mixed solvent }\right)\end{array}$ \\
\hline \multicolumn{6}{|l|}{ Toc and Toc-3 } \\
\hline$\alpha$-Toc & $3.16 \times 10^{8}$ & $2.05 \times 10^{8}$ & 1.54 & $1.31 \times 10^{8}$ & 2.41 \\
\hline$\alpha$-Toc-3 & $3.75 \times 10^{8}$ & $2.24 \times 10^{8}$ & 1.67 & $1.22 \times 10^{8}$ & 3.07 \\
\hline$\beta$-Toc & $2.52 \times 10^{8}$ & $1.86 \times 10^{8}$ & 1.35 & $9.45 \times 10^{7}$ & 2.67 \\
\hline$\beta$-Toc-3 & $2.88 \times 10^{8}$ & $1.87 \times 10^{8}$ & 1.54 & $1.05 \times 10^{8}$ & 2.74 \\
\hline$\gamma$-Toc & $2.28 \times 10^{8}$ & $1.58 \times 10^{8}$ & 1.44 & $8.15 \times 10^{7}$ & 2.80 \\
\hline$\gamma$-Toc-3 & $3.07 \times 10^{8}$ & $1.54 \times 10^{8}$ & 1.99 & $8.14 \times 10^{7}$ & 3.77 \\
\hline$\delta$-Toc & $1.09 \times 10^{8}$ & $6.63 \times 10^{7}$ & 1.64 & $4.79 \times 10^{7}$ & 2.28 \\
\hline$\delta$-Toc-3 & $1.48 \times 10^{8}$ & $6.93 \times 10^{7}$ & 2.13 & $4.97 \times 10^{7}$ & 2.98 \\
\hline & & & av 1.66 & & av 2.84 \\
\hline
\end{tabular}

${ }^{\mathrm{a}} k_{\mathrm{Q}}{ }^{\mathrm{AO}}(S)$ is abbreviated as $k_{\mathrm{Q}}{ }^{\mathrm{AO}}$ for the sake of simplicity.

${ }^{\mathrm{b}} \mathrm{The} k_{\mathrm{Q}}{ }^{\mathrm{AO}}(\mathrm{EtOH})$ and $k_{\mathrm{Q}}{ }^{\mathrm{AO}}$ (mixed solvent) values reported in Ref. (34).

$\gamma$-Toc $>\delta$-Toc- $3>\delta$-Toc

The values of the ratios $\left(k_{Q}{ }^{T o c}-3(S) / k_{Q}{ }^{T o c}(S)\right)$ for $\alpha-, \beta-$, $\gamma$-, and $\delta$-Toc and -Toc-3 are $1.19,1.14,1.35$, and 1.36 , respectively. The result clearly indicates that the ${ }^{1} \mathrm{O}_{2}$-quenching rates of Toc-3 are larger than those of the corresponding Toc in a micellar solution.

Toc-3 differs from Toc in the chemical nature of the side chain or tail. Toc has a saturated phytyl side chain, whereas Toc-3 has an unsaturated isoprenoid (or farnesyl) side chain (Fig. S2). A phytyl side chain will have a straight molecular structure. On the other hand, an unsaturated isoprenoid side chain possessing three double bonds will have a bent structure and shorter chain length than that of a phytyl side chain. This will give a change in the mobility of Toc and Toc-3 in a micellar solution. That is, the mobility of Toc- 3 will be higher than that of Toc.

As listed in Table 6 , the $k_{Q}{ }^{\text {Toc and Toc-3 }}$ values decreased in the following order:

$k_{\mathrm{Q}}^{\text {Toc and Toc-3 }}($ micelle $)>k_{\mathrm{Q}}^{\text {Toc and Toc-3 }}(\mathrm{EtOH})>$

$k_{\mathrm{Q}}{ }^{\text {Toc and Toc-3 }}$ (mixed solvent)

The ratios of $k_{0}$ Toc and Toc-3 (micelle) to $k_{0}{ }^{\text {Toc and Toc-3 }}$ (mixed solvent) and $k_{\mathrm{Q}}{ }^{\text {Toc and Toc-3 }}(\mathrm{EtOH})$ for Toc and Toc-3 are 2.84 and 1.66, respectively (Eqs. (12) and (13)).

$k_{\mathrm{Q}}^{\text {Toc and Toc-3 }}($ micelle $)=2.84 k_{\mathrm{Q}}^{\text {Toc and Toc-3 }}($ mixed solvent)

$k_{\mathrm{Q}}^{\text {Toc and Toc-3 }}($ micelle $)=1.66 k_{\mathrm{Q}}^{\text {Toc and Toc-3 }}(\mathrm{EtOH})$

As 4 Toc and 4 Toc- 3 are lipophilic, they are expected to localize within the micelle. Consequently, the local concentrations of these AO in a Triton X-100 micellar solution $(5.0 \mathrm{wt} \%)$ should become $\sim 20$ times larger than in a homogeneous ethanol solution (or mixed solvent), if one assumes that the volume that Triton X-100 molecules ( $5.0 \mathrm{wt} \%$ ) occupy in a micellar solution is $5.0 \%$ of the total volume. As the ${ }^{1} \mathrm{O}_{2}$ molecule is also lipid soluble (50), it is also expected to react with these AOs inside of the micelle. Therefore, if the polarity of the reaction field between ${ }^{1} \mathrm{O}_{2}$ and $\mathrm{AO}$ in a micellar solution is similar to that of ethanol, the $k_{Q}$ values of the AOs observed in micelles should become 20 times larger than those in ethanol. To our surprise, however, the $k_{\mathrm{Q}}{ }^{\text {Toc and Toc-3 }}$ (micelle) $/ k_{\mathrm{Q}}{ }^{\text {Toc and Toc-3 }}(\mathrm{EtOH})$ ratio observed was only 1.66, as determined from Eq. (13).

As shown in Fig. S2, the 4 Toc and 4 Toc-3 investigated contain different numbers of $\mathrm{CH}_{3}$ groups at an aromatic phenol ring and contain different side chains. Therefore, one might expect that the Toc and Toc-3 molecules are located at the positions having different polarities (i.e., different $\varepsilon$ values) in a micellar solution. However, the measured $\lambda_{\max }$ values of the Toc and Toc-3 suggest that the part of polar head phenolic ring in 4 Toc and 4 Toc-3 molecules is localized to an environment with a polarity similar to that of chloroform (see Table S2) (38).

Gruszka et al. (49) reported that the ${ }^{1} \mathrm{O}_{2}$-quenching rate constants $\left(k_{\mathrm{Q}}\right)$ of $\alpha-, \beta-, \gamma$, and $\delta$-Toc increase linearly with an increasing solvent dielectric constant $(\varepsilon)$ (i.e., polarity). The values of ratios ( $k_{Q}(\mathrm{EtOH}, \varepsilon=24.58)$ / $\left.k_{\mathrm{Q}}\left(\mathrm{CHCl}_{3}, \varepsilon=4.806\right)\right)$ estimated from the $k_{\mathrm{Q}}$ versus $\varepsilon$ plot (see Fig. 2 in Ref. (49)) are ca. 1.8, 2.7, 3.3, and 3.0 for $\alpha-, \beta-, \gamma$, and $\delta$-Toc, respectively. Even after taking into account the decrease in $k_{\mathrm{Q}}{ }^{\text {Toc and Toc-3 }}$ in chloroform described above, the small values of the observed ratios (i.e., 1.66), which are much smaller than the expected ratio of $\sim 20$, cannot be explained. The significant decrease in the $k_{0}{ }^{\text {Toc and Toc- } 3}$ values of Toc and Toc- 3 may be due to suppression of the mobility of Toc and Toc-3 molecules in the heterogeneous micellar solution (37, $38,51-53)$.

Toc- 3 has received much attention in recent years $(54,55)$. Some biological functions such as cholesterol lowering, anti-cancer, anti-inflammatory, anti-angiogenic, and neuroprotection effects have been reported for Toc-3. These findings suggest that Toc-3 has a wide variety of health benefits. The difference in biological activity of Toc and Toc-3 may relate to the difference of 
Table 7. The $k_{\mathrm{Q}}{ }^{\mathrm{AO}}$ values for antioxidants (AOs) in a Triton X-100 (5.0 wt \%) micellar solution (pH 7.4), ethanol, and mixed solvent, and their ratios $\left(k_{\mathrm{Q}}(\right.$ micelle $) / k_{\mathrm{Q}}(\mathrm{EtOH})$ and ${k_{\mathrm{Q}}}^{\mathrm{AO}}($ micelle $) / k_{\mathrm{Q}}{ }^{\mathrm{AO}}$ (mixed solvent)).

\begin{tabular}{|c|c|c|c|c|c|}
\hline $\begin{array}{l}\text { Antioxidant } \\
\text { (AO) }\end{array}$ & $\begin{array}{c}k_{Q}^{\mathrm{AOa}} \\
(\mathrm{pH} 7.4) \\
/ \mathrm{M}^{-1} \mathrm{~s}^{-1} \\
\text { micelle }\end{array}$ & $\begin{array}{c}k_{Q}{ }^{\mathrm{AO}} \\
/ \mathrm{M}^{-1} \mathrm{~s}^{-1} \\
\mathrm{EtOH}^{\mathrm{b}}\end{array}$ & $\begin{array}{c}k_{\mathrm{Q}}{ }^{\mathrm{AO}}(\text { micelle }) / \\
k_{\mathrm{Q}}{ }^{\mathrm{AO}}(\mathrm{EtOH})\end{array}$ & $\begin{array}{c}k_{Q}{ }^{A O} \\
/ M^{-1} s^{-1} \\
\text { mixed solvent }{ }^{b}\end{array}$ & $\begin{array}{c}k_{Q}{ }^{A O}(\text { micelle }) / \\
k_{Q}{ }^{A O}(\text { mixed solvent })\end{array}$ \\
\hline$\alpha$-Tocopherol & $3.16 \times 10^{8}$ & $2.06 \times 10^{8}$ & & $1.31 \times 10^{8}$ & \\
\hline Lycopene & low solubility & low solubility & & $1.38 \times 10^{10}$ & \\
\hline Astaxanthin & $7.11 \times 10^{9}$ & low solubility & & $1.18 \times 10^{10}$ & 0.602 \\
\hline$\beta$-Carotene & $4.23 \times 10^{9}$ & $1.71 \times 10^{10}$ & 0.247 & $1.08 \times 10^{10}$ & 0.393 \\
\hline Capsanthin & $4.54 \times 10^{9}$ & $1.79 \times 10^{10}$ & 0.254 & $1.06 \times 10^{10}$ & 0.425 \\
\hline Zeaxanthin & $5.83 \times 10^{9}$ & $1.82 \times 10^{10}$ & 0.320 & $1.05 \times 10^{10}$ & 0.555 \\
\hline$\alpha$-Carotene & $5.70 \times 10^{9}$ & $1.92 \times 10^{10}$ & 0.297 & $9.76 \times 10^{9}$ & 0.584 \\
\hline Lutein & $5.53 \times 10^{9}$ & $1.76 \times 10^{10}$ & 0.314 & $9.24 \times 10^{9}$ & 0.598 \\
\hline$\beta$-Cryptoxanthin & $4.40 \times 10^{9}$ & $1.54 \times 10^{10}$ & $\begin{array}{c}0.286 \\
\text { av } 0.286 \pm 0.012\end{array}$ & $7.31 \times 10^{9}$ & $\begin{array}{c}0.602 \\
\text { av } 0.530 \pm 0.034\end{array}$ \\
\hline
\end{tabular}

${ }^{\mathrm{a}} k_{\mathrm{Q}}{ }^{\mathrm{AO}}(S)$ is abbreviated as $k_{Q}{ }^{\mathrm{AO}}$ for the sake of simplicity.

${ }^{\mathrm{b}} k_{\mathrm{Q}}{ }^{\mathrm{AO}}(\mathrm{EtOH})$ and $k_{\mathrm{Q}}{ }^{\mathrm{AO}}$ (mixed solvent) values reported in Ref. (33).

the mobility of Toc and Toc-3, although the details are not clear at present. Measurements of $k_{Q}$ and SOAC values in a micellar solution may be useful for evaluating the ${ }^{1} \mathrm{O}_{2}$-quenching activity of AOs in biological systems.

Further, similar measurements of $k_{0}{ }^{\mathrm{AO}}$ (micelle) values were performed for 7 Cars in a micellar solution (37). The ratios of $k_{Q}{ }^{\mathrm{Car}}$ (micelle) to $k_{Q}{ }^{\mathrm{Car}}$ (mixed solvent) and $k_{Q}{ }^{\mathrm{Car}}(\mathrm{EtOH})$ for Cars were calculated to be 0.530 and 0.286 , respectively (see Table 7 ).

$$
\begin{aligned}
& k_{Q}{ }^{\text {Car }}(\text { micelle })=0.530 k_{Q}{ }^{\text {Car }}(\text { mixed solvent }) \\
& k_{Q}{ }^{\text {Car }}(\text { micelle })=0.286 k_{Q}{ }^{\text {Car }}(\text { EtOH })
\end{aligned}
$$

As Eqs. (14) and (12) indicate, the values of the ratios $\left(k_{\mathrm{Q}}{ }^{\mathrm{Car}}(\right.$ micelle $\left.) / k_{\mathrm{Q}}{ }^{\mathrm{Car}}(\mathrm{EtOH})=0.286\right)$ for Cars are smaller than those for Toc and Toc-3 ( $k_{\mathrm{Q}}^{\text {Toc and Toc-3 }}$ (micelle)/ $\left.k_{\mathrm{Q}}^{\text {Toc and Toc-3 }}(\mathrm{EtOH})=1.66\right)$. The value of the latter is about 5.8 times larger than the former, and suggests that the mobility of the 7 Cars, which exhibit rigid molecular structures, should be more suppressed than those of Toc and Toc- 3 in a micellar solution, resulting in greater decreases in $k_{Q}{ }^{\text {Car }}$ than $k_{Q}{ }^{\text {Toc and Toc-3 }}$. Furthermore, differences in the ratios $(0.286$ and 1.66$)$ between Cars and Toc and Toc-3 may also be due to differences in the rigidity of the regions at which Cars and Toc and Toc-3 molecules are localized. However, details are not clear at present.

Fukuzawa et al. $(52,53)$ indicated that notable variations of the $k_{Q}$ values of AOs in homogeneous ethanol and heterogeneous liposome solutions may be explained by (i) polarity (dielectric constant $(\varepsilon)$ ) of reaction field between $\mathrm{AOs}$ and ${ }^{1} \mathrm{O}_{2}$, (ii) local concentration of AOs, and (iii) mobility of AOs in solutions. The results obtained in the present study also support the explanation given above, although large differences were observed for the $k_{Q}$ values of AOs between micellar and liposome solutions.

As described above, the method to evaluate the ${ }^{1} \mathrm{O}_{2}$-quenching activity of natural AOs and food and

\begin{tabular}{|c|c|c|c|c|c|c|}
\hline & 1 & 2 & 3 & 4 & 5 & 6 \\
\hline A & Blank & $\begin{array}{c}\alpha \text {-Toc } \\
500 \mu \mathrm{M}\end{array}$ & $\begin{array}{c}\text { Sample } 1 \\
\times 0.2\end{array}$ & $\begin{array}{c}\text { Sample } 1 \\
\times 0.3\end{array}$ & $\begin{array}{c}\text { Sample 1 } \\
\times 0.6\end{array}$ & $\begin{array}{c}\text { Sample } 1 \\
\times 1.0\end{array}$ \\
\hline B & $\begin{array}{c}\text { Sample } 2 \\
\times 1.0\end{array}$ & $\begin{array}{c}\text { Sample 2 } \\
\times 0.6\end{array}$ & $\begin{array}{c}\text { Sample } 2 \\
\times 0.3\end{array}$ & $\begin{array}{c}\text { Sample } 2 \\
\times 0.2\end{array}$ & $\begin{array}{c}\alpha \text {-Toc } \\
500 \mu \mathrm{M}\end{array}$ & Blank \\
\hline $\mathrm{C}$ & Blank & $\begin{array}{c}\alpha-\text { Toc } \\
500 \mu \mathrm{M}\end{array}$ & $\begin{array}{c}\text { Sample } 3 \\
\times 0.2\end{array}$ & $\begin{array}{c}\text { Sample } 3 \\
\times 0.3\end{array}$ & $\begin{array}{c}\text { Sample } 3 \\
\times 0.6\end{array}$ & $\begin{array}{c}\text { Sample } 3 \\
\times 1.0\end{array}$ \\
\hline D & Blank & $\begin{array}{c}\text { Sample } 3 \\
\times 1.0\end{array}$ & $\begin{array}{c}\text { Sample } 2 \\
\times 1.0\end{array}$ & $\begin{array}{c}\text { Sample } 1 \\
\times 1.0\end{array}$ & $\begin{array}{c}\alpha-\text { Toc } \\
500 \mu \mathrm{M}\end{array}$ & Blank \\
\hline
\end{tabular}
plant extracts in organic solvents and a Triton X-100
Fig. 5. Layout of the 24-well microplate. Gray wells (line D) are baseline wells in which DPBF and EP are not contained. The number of sample wells represents the sample dilution factor. The concentration of $\alpha$-Toc $(500 \mu \mathrm{M})$ is final concentration.

micellar solution was established. It is well-known that representative AOs (such as $\alpha$-Toc, $\mathrm{UQ}_{10} \mathrm{H}_{2}$, Cars, and Vit C) are contained in human plasma (56). Catechins are also found in plasma following oral ingestion (57). As endoperoxide (EP), DPBF, and plasma are soluble in a Triton X-100 micellar solution (5.0 wt \%, pH 7.4), we have recently succeeded in measuring the $k_{\mathrm{Q}}(S)$ and SOAC values of plasma (to be published). $\alpha$-Toc and $\mathrm{UQ}_{10} \mathrm{H}_{2}$ are contained in mice tissues (heart, liver, kidney, and brain (homogenate and mitochondria)) and their concentrations were reported (56). Measurements of the SOAC value of mice tissues will be interesting to clarify the ${ }^{1} \mathrm{O}_{2}$-quenching activity of biological systems.

\section{Measurements of the $k_{Q}$ and SOAC Values of Antioxidants and Food Extracts Using a Microplate Reader}

As described above, the $k_{Q}$ and SOAC values were measured in organic solvents and a micellar solution at $35^{\circ} \mathrm{C}$, using an UV-vis spectrophotometer equipped with 
Table 8. Second-order rate constants $\left(k_{Q}(S)\right.$ and $\left.k_{Q}\left(t_{1 / 2}\right)\right)$ for $\alpha$-tocopherol, eight carotenoids, and three vegetable extracts measured using a microplate reader and an UV-vis spectrophotometer equipped with a six-channel cell positioner.

\begin{tabular}{|c|c|c|c|c|}
\hline \multirow{2}{*}{$\begin{array}{l}\text { Carotenoid } \\
\quad(\text { Car })\end{array}$} & \multicolumn{2}{|l|}{$k_{\mathrm{Q}}(S) / \mathrm{M}^{-1} \mathrm{~s}^{-1}$} & \multicolumn{2}{|l|}{$k_{\mathrm{Q}}\left(t_{1 / 2}\right) / \mathrm{M}^{-1} \mathrm{~s}^{-1}$} \\
\hline & Microplate reader ${ }^{a}$ & $\begin{array}{l}\text { UV-vis spectro- } \\
\text { photometer }\end{array}$ & Microplate reader ${ }^{\mathrm{a}}$ & $\begin{array}{l}\text { UV-vis spectro- } \\
\text { photometer }\end{array}$ \\
\hline$\alpha$-Тoc & $(1.10 \pm 0.07) \times 10^{8}$ & $1.06 \times 10^{8}$ & $(1.12 \pm 0.06) \times 10^{8}$ & $1.03 \times 10^{8}$ \\
\hline Lycopene & $(1.46 \pm 0.13) \times 10^{10}$ & $1.48 \times 10^{10}$ & $(1.44 \pm 0.11) \times 10^{10}$ & $1.38 \times 10^{10}$ \\
\hline Astaxanthin & $(1.22 \pm 0.07) \times 10^{10}$ & $1.07 \times 10^{10}$ & $(1.20 \pm 0.06) \times 10^{10}$ & $1.05 \times 10^{10}$ \\
\hline Capsanthin & $(1.10 \pm 0.09) \times 10^{10}$ & $1.15 \times 10^{10}$ & $(1.05 \pm 0.07) \times 10^{10}$ & $1.10 \times 10^{10}$ \\
\hline Zeaxanthin & $(1.03 \pm 0.04) \times 10^{10}$ & $9.90 \times 10^{9}$ & $(1.03 \pm 0.04) \times 10^{10}$ & $9.59 \times 10^{9}$ \\
\hline$\beta$-Carotene & $(1.02 \pm 0.06) \times 10^{10}$ & $1.02 \times 10^{10}$ & $(9.74 \pm 0.64) \times 10^{9}$ & $9.94 \times 10^{9}$ \\
\hline$\alpha$-Carotene & $(9.17 \pm 0.35) \times 10^{9}$ & $9.88 \times 10^{9}$ & $(8.88 \pm 0.68) \times 10^{9}$ & $9.76 \times 10^{9}$ \\
\hline Lutein & $(7.42 \pm 0.36) \times 10^{9}$ & $8.81 \times 10^{9}$ & $(7.58 \pm 0.39) \times 10^{9}$ & $8.12 \times 10^{9}$ \\
\hline$\beta$-Cryptoxanthin & $(7.54 \pm 0.70) \times 10^{9}$ & $7.26 \times 10^{9}$ & $(8.24 \pm 0.27) \times 10^{9}$ & $6.84 \times 10^{9}$ \\
\hline \multirow[b]{2}{*}{ Vegetable extract } & $k_{\mathrm{Q}}(S) / \mathrm{L} \mathrm{g}^{-1} \mathrm{~s}^{-1}$ & \multicolumn{3}{|c|}{$k_{\mathrm{Q}}\left(t_{1 / 2}\right) / \mathrm{L} \mathrm{g}^{-1} \mathrm{~s}^{-1}$} \\
\hline & Microplate reader ${ }^{\mathrm{a}}$ & $\begin{array}{c}\text { UV-vis } \\
\text { spectro-photometer }\end{array}$ & Microplate reader ${ }^{\mathrm{a}}$ & $\begin{array}{c}\text { UV-vis } \\
\text { spectro-photometer }\end{array}$ \\
\hline Tomato & $(1.56 \pm 0.04) \times 10^{4}$ & $1.52 \times 10^{4}$ & $(1.56 \pm 0.07) \times 10^{4}$ & $1.38 \times 10^{4}$ \\
\hline Carrot & $(1.63 \pm 0.08) \times 10^{4}$ & $1.55 \times 10^{4}$ & $(1.52 \pm 0.06) \times 10^{4}$ & $1.49 \times 10^{4}$ \\
\hline Red paprika & $(1.63 \pm 0.10) \times 10^{4}$ & $1.62 \times 10^{4}$ & $(1.48 \pm 0.13) \times 10^{4}$ & $1.54 \times 10^{4}$ \\
\hline
\end{tabular}

${ }^{\mathrm{a}}$ Data are represented as means \pm SD $(n=3)$.

a six-channel cell positioner and an electron-temperature control unit. Recently, Takahashi et al. (39) have succeeded in measuring the $k_{\mathrm{Q}}$ and SOAC values using a versatile instrument, microplate reader. A 24-well glass microplate (Fig. 5) was used for measurements, because a plastic microplate, which is generally used in laboratory, dissolves in the above mixed solvent. Measurements of the $k_{Q}$ and SOAC values were performed for 8 representative carotenoids and 3 vegetable extracts (tomato, carrot, and red paprika). The $k_{\mathrm{Q}}(S)$ and $k_{\mathrm{Q}}\left(t_{1 / 2}\right)$ and SOAC values of eight Cars and three vegetable extracts measured using a microplate reader were in good agreement with the corresponding those measured using an UV-vis spectrophotometer, as listed in Table 8 and Table S3, respectively. The result suggests that the microplate reader is applicable to measure reliable SOAC values for general AOs and food extracts in solution.

Using a microplate reader, it is possible to measure the SOAC value for three kinds of AOs simultaneously. It is a merit to use a microplate reader for the measurement of SOAC value. However, it is necessary to analyze pseudo-first-order rate constants $\left(S_{\text {blank }}\right.$ and $\left.S_{\mathrm{AO}}\right)$ and half-lives $\left(t_{1 / 2}{ }^{\text {blank }}\right.$ and $\left.t_{1 / 2}{ }^{\mathrm{AO}}\right)$ (see Eqs. (3) and (4)) carefully, because the time range $(40<t<70 \mathrm{~min})$ that $\ln$ (Absorbance) vs [AO] (or [Blank]) plot shows a straight line is narrow in the case of a microplate reader, differing from that $(5<t<60 \mathrm{~min})$ in the case of an UV-vis spectrophotometer (Fig. 6). It took about $40 \mathrm{~min}$ before the solution temperature in 24-well glass microplate reaches $35^{\circ} \mathrm{C}$ (i.e. a steady-state), and, further, the formation rate of ${ }^{1} \mathrm{O}_{2}$ decreased gradually due to the con- sumption of EP after $70 \mathrm{~min}$.

Recently, ${ }^{1} \mathrm{O}_{2}$-quenching activities of 32 kinds of fruits and vegetables typically consumed in Japan were evaluated using the SOAC method (40).

\section{Validation Study}

The precision of the SOAC assay method was evaluated in an inter-laboratory validation study (41). SOAC values were measured for 3 AO solutions (i.e. capsanthin, zeaxanthin, and astaxanthin solutions) and 3 food extracts (i.e. tomato, red paprika, and carrot extracts), using a 24-well glass microplate. This study involved 14 participating laboratories, with data sets from 8 successfully participating laboratories subjected to statistical analysis. In accordance with the harmonized protocol, this study showed that the intermediate precision relative standard deviation (RSDint) and the reproducibility relative standard deviation (RSDR) ranged from 3.4 to $9.9 \%$, and from 6.2 to $14.0 \%$, respectively, and the HorRat values ranged from 0.87 to 1.97 . Therefore, the SOAC assay method was validated by this inter-laboratory study in accordance with the internationally harmonized protocol.

\section{Conclusions}

Lipid peroxyl radical (LOO·) and singlet oxygen $\left({ }^{1} \mathrm{O}_{2}\right)$ are well known as two representative reactive oxygen species (ROS) generated in biological systems. The method to assess the total oxygen radical absorption capacity (ORAC) of foods and plants has been established by several investigators $(58-60)$. On the other 

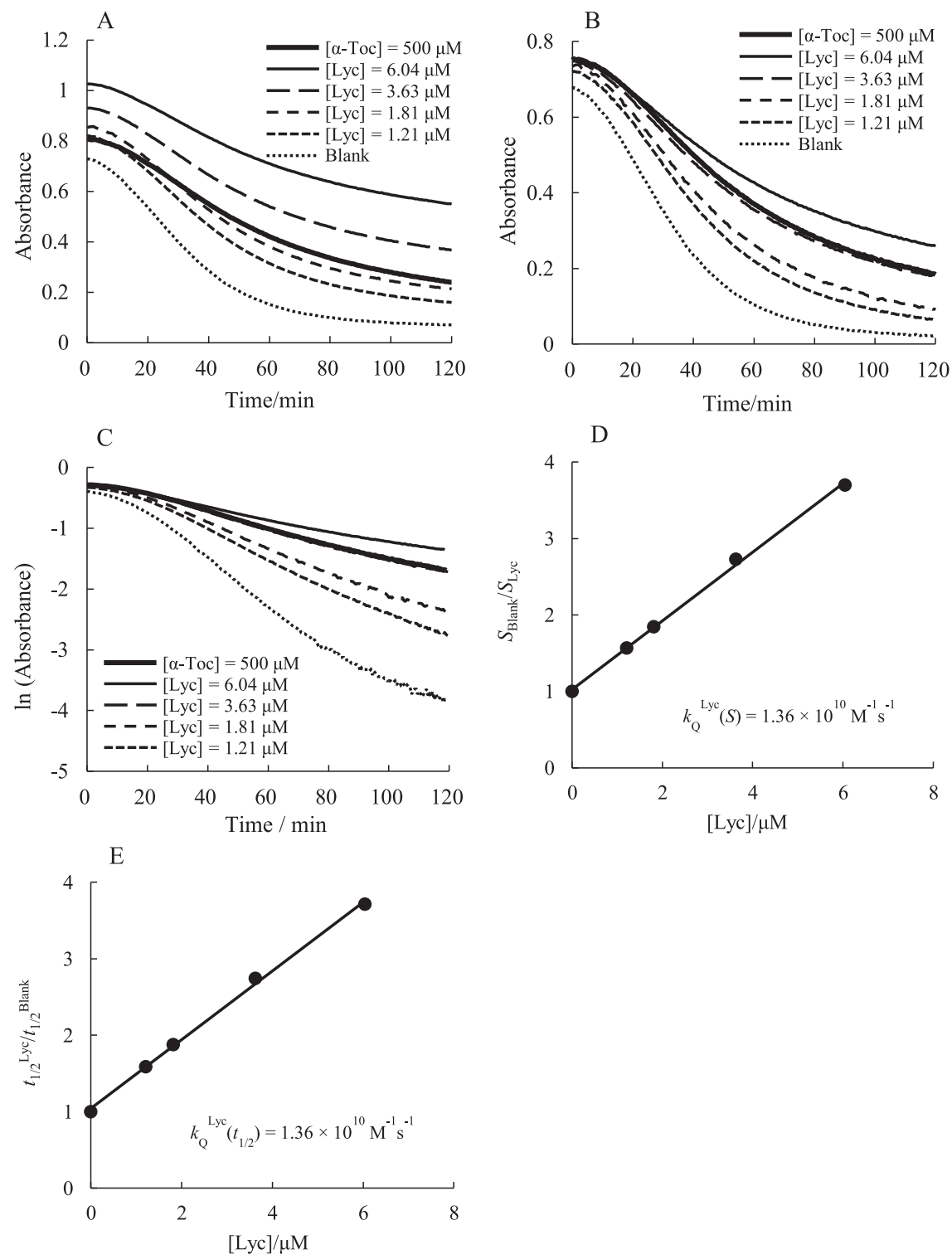

Fig. 6. (A) Change in absorbance of DPBF at $413 \mathrm{~nm}$ during the reaction of DPBF with ${ }^{1} \mathrm{O}_{2}$ in the absence and presence of sample $\left(\alpha\right.$-Toc and Lyc) in ethanol/chloroform $/ \mathrm{D}_{2} \mathrm{O}$ at $35^{\circ} \mathrm{C}$. $[\mathrm{DPBF}]=0.0614 \mathrm{mM}$ and $[\mathrm{EP}]=0.546 \mathrm{mM}$. The values of $[\alpha$-Toc] and [Lyc] are shown in A. (B) Change in absorbance of DPBF, where the correction of baseline due to Lyc was performed (see text). (C) Plot of $\ln$ (Absorbance) vs time. (D) Plot of $S_{\text {blank }} / S_{\text {Lyc }}$ vs [Lyc]. (E) Plot of $t_{1 / 2}{ }^{\text {Lyc }} / t_{1 / 2}{ }^{\text {blank }}$ vs [Lyc].

hand, a SOAC assay method to assess the total quenching activity of ${ }^{1} \mathrm{O}_{2}$ by foods and plants has not been established. Consequently, the development of the SOAC assay method is very important. In our laboratory, first, the quenching rates $\left(k_{0}\right)$ of ${ }^{1} \mathrm{O}_{2}$ by 8 representative Cars, $\alpha$-Toc, and three kinds of vegetable extracts containing high concentrations of Cars (i.e. tomato, carrot, and red paprika) were measured in ethanol/chloroform/ $\mathrm{D}_{2} \mathrm{O}$ solution at $35^{\circ} \mathrm{C}$, by using the competition reaction method (Scheme 1) $(31,32)$. From the results, the method to assess the total SOAC value of the AOs included in foods and plants has been proposed.

Many kinds of natural phenolic AOs (Table 2) are included in foods, plants, and animals, and may function as ${ }^{1} \mathrm{O}_{2}$-quencher in biological systems. Therefore, in order to ascertain that the SOAC assay method proposed for Cars is applicable to general phenolic AOs, measure- ments of $k_{0}$ and relative SOAC values were performed for the above phenolic AOs in mixed solvent. From the results, it has been clarified that the SOAC assay method is applicable to a variety of natural AOs having five orders of magnitude different ${ }^{1} \mathrm{O}_{2}$-quenching rates $\left(k_{0}\right)$ (33). Measurements of the $k_{0}$ and SOAC values were also performed for 39 kinds of food extracts, indicating that the SOAC method is useful to evaluate the ${ }^{1} \mathrm{O}_{2}$-quenching activity of food extracts having two orders of magnitude different rate constants $\left(k_{Q}\right)(28,34-36)$.

Further, the $k_{0}$ and SOAC values for the reaction of ${ }^{1} \mathrm{O}_{2}$ with 8 Cars and 8 vitamin $\mathrm{E}$ homologues were measured in an aqueous Triton X-100 (5.0 wt \%) micellar solution ( $\mathrm{pH} 7.4$ ), which was used as a simple model of biomembranes $(37,38)$. Results obtained demonstrate that the $k_{Q}$ values of AOs in homogeneous and heterogeneous solutions vary notably depending on (i) polar- 
ity (dielectric constant $(\varepsilon)$ ) of the reaction field between AOs and ${ }^{1} \mathrm{O}_{2}$, (ii) local concentration of AOs, and (iii) mobility of AOs in solution. Measurements of $k_{0}$ and SOAC values in a micellar solution may be useful for evaluating the ${ }^{1} \mathrm{O}_{2}$-quenching activity of $\mathrm{AOs}$ in biological systems.

Furthermore, measurements of the SOAC values were performed for 32 kinds of vegetable and fruit extracts using a versatile instrument, microplate reader (39, 40 ). The SOAC values measured using a microplate reader were in good agreement with the corresponding those measured using an UV-vis spectrophotometer. The SOAC assay method was validated by inter-laboratory validation study due to 14 laboratories (41).

As described in Introduction, the high reactivity of ${ }^{1} \mathrm{O}_{2}$ causes oxidative damage to biomolecules such as lipids (10-12), proteins $(3,4)$, and DNA (13-15). For example, lipids, particularly polyunsaturated fatty acids (PUFAs), are frequent targets of in vivo ${ }^{1} \mathrm{O}_{2}$ oxidation, producing lipid hydroperoxides. Generation of lipid hydroperoxides is associated with disease onset such as diabetes (61). The relationship between in vivo ROS production (including ${ }^{1} \mathrm{O}_{2}$ ) and the onset of diseases such as Alzheimer's disease, Parkinson's disease, and diabetes was described in the reviews of Terao (1) and Umeno et al. (61).

\section{Disclosure of State of COI}

No conflicts of interest to be declared.

\section{Acknowledgments}

I am very grateful to (i) Dr. Aya Ouchi and Prof. Shinichi Nagaoka of Ehime University, (ii) Ms. Yuko Iwasaki, Mr. Shingo Takahashi, Dr. Koichi Aizawa, and Dr. Takahiro Inakuma of Kagome Co. Ltd., and (iii) Prof. Junji Terao of Tokushima University for collaboration with the development of SOAC assay method.

\section{Supporting Information}

Supplemental Online Material is available on J-STAGE.

\section{REFERENCES}

1) Terao, J. 2016. Production and quenching of singlet molecular oxygen-Its role in oxidative stress-, Vitamins (Japan) 99: 525-536, and references are cited therein.

2) Miyamoto S, Martinez GR, Medeiros MHG, Di Mascio P. 2014. Singlet molecular oxygen generated by biological hydroperoxides. J Photochem Photobiol B 139: 24-33.

3) Davies MJ, Truscott RJW. 2001. Photo-oxidation of proteins and its role in cataractogenesis. J Photochem Photobiol B Biol 63: 114-125, and references are cited therein.

4) Davies MJ. 2003. Singlet oxygen-mediated damage to proteins and its consequences. Biochem Biophys Res Commun 305: 761-770.

5) Russel DA. 1957. Deuterium-isotope effects in the autoxidation of alkyl hydrocarbons. Mechanism of the interaction of peroxyl radicals. J Am Chem Soc 79: 3871-3877.

6) Miyamoto S, Martinez GR, Medeiros MHG, Di Mascio P. 2003. Singlet molecular oxygen generated from lipid hydroperoxides by the Russel mechanism: Studies using ${ }^{18} \mathrm{O}$-labeled linoleic acid hydroperoxide and monomol light emission measurements. J Am Chem Soc 125: 4510-4517.

7) Steinbeck MJ, Khan AU, Karnovsky MJ. 1992. Intracellular singlet oxygen generation by phagocytosing neutrophils in response to particles coated with a chemical trap. J Biol Chem 267: 13425-13433.

8) Miyamoto S, Martinez GR, Rettori D, Augusto O, Medeiros MHG, Di Mascio P. 2006. Linoleic acid hydroperoxide reacts with hypochlorous acid, generating peroxyl radical intermediates and singlet molecular oxygen. Proc Natl Acad Sci USA 103: 293-298.

9) Miyamoto S, Nantes IL, Faria PA, Cunha D, Ronsein GE, Medeiros MHG, Di Mascio P. 2012. Cytochrome c-promoted cardiolipin oxidation generates singlet molecular oxygen. Photochem Photobiol Sci 11: 1536-1546.

10) Terao J, Matsushita S. 1977. Products formed by photosensitized oxidation of unsaturated fatty acid esters. $J$ Am Oil Chem Soc 54: 234-238.

11) Girotti AW. 1990. Photodynamic lipid peroxidation in biological systems. Photochem Photobiol 51: 497-509.

12) Bando N, Hayashi H, Wakamatsu S, Inakuma T, Miyoshi M, Nagao A, Yamauchi R, Terao J. 2004. Participation of singlet oxygen in ultraviolet-A-induced lipid peroxidation in mouse skin and its inhibition by dietary $\beta$-carotene: an ex vivo study. Free Radical Biol Med 37: 1854-1863.

13) Devasagayam TPA, Steenken S, Obendorf MSW, Schulz WA, Sies H. 1991. Formation of 8-(hydroxy(deoxy) guanosine and generation of strand breaks at guanine residues in DNA by singlet oxygen. Biochemistry 30: 6283-6289.

14) Piette J. 1991. New trends in photobiology: Biological consequences associated with DNA oxidation mediated by singlet oxygen. J Photochem Photobiol B Biol 11: 241-260.

15) Duarte V, Gasparutto D, Yamaguchi LF, Ravanat J-L, Medeiros MHG, Di Mascio P, Cadnet J. 2000. Oxaluric acid as the major product of singlet oxygen-mediated oxidation of 8-oxo-7,8-dihydroguanine in DNA. J Am Chem Soc 122: 12622-12628.

16) Mangels AR, Holden JM, Beecher GR, Forman MR, Lanza E. 1993. Carotenoid content of fruits and vegetables: an evaluation of analytic data. J Am Diet Assoc 93: 284-296.

17) Holden JM, Eldridge AL, Beecher GR, Buzzard IM, Bhagwat S, Davis CS, Douglass LW, Gebhardt S, Haytowitz D, Schakel S. 1999. Carotenoids content of U.S. foods: An update of database. J Food Compos Anal 12: 169-196.

18) Aizawa K, Inakuma T. 2007. Quantitation of carotenoids in commonly consumed vegetables in Japan. Food Sci Technol Res 13: 247-252.

19) Sookwong P, Nakagawa K, Murata K, Kojima $Y$, Miyazawa T. 2007. Quantitation of tocotrienol and tocopherol in various rice brans. J Agric Food Chem 55: 461-466.

20) Tuberoso CIG, Kowalczyk A, Sarritzu E, Cabras P. 2007. Determination of antioxidant compounds and antioxidant activity in commercial oilseeds for food use. Food Chem 103: 1494-1501.

21) $\mathrm{Hu}$ J-N, Zhu X-M, Adhikari P, Li D, Kim I-H, Lee K-T. 2009. Determination of tocopherol contents in refined edible oils using an HPLC method. J Food Sci Nutr 14: 260-264. 
22) Foote CS, Denny RW. 1968. Chemistry of singlet oxygen. VII. Quenching by $\beta$-carotene. J Am Chem Soc 90: 6233-6235.

23) Foote CS, Ching T-Y, Geller GG. 1974. Chemistry of singlet oxygen-XVIII. Rates of reaction and quenching of $\alpha$-tocopherol and singlet oxygen. Photochem Photobiol 20: $511-513$.

24) Di Mascio P, Kaiser S, Sies H. 1989. Lycopene as the most efficient biological carotenoid singlet oxygen quencher. Arch Biochem Biophys 274: 532-538.

25) Sies H, Stahl W, Sundquist AR. 1992. Antioxidant functions of vitamins. Vitamin $\mathrm{E}$ and $\mathrm{C}, \beta$-carotene, and other carotenoids. Ann NY Acad Sci 669: 7-20.

26) Di Mascio P, Sundquist AR, Devasagayam TPA, Sies H. 1992. Assay of lycopene and other carotenoids as singlet oxygen quenchers. Methods Enzymol 213: 429-438.

27) Mukai K, Daifuku K, Okabe K, Tanigaki T, Inoue K. 1991. Structure-activity relationship in the quenching reaction of singlet oxygen by tocopherol (vitamin E) derivatives and related phenols. Finding of linear correlation between the rates of quenching of singlet oxygen and scavenging of peroxyl and phenoxyl radicals in solution. J Org Chem 56: 4188-4192.

28) Mukai K, Ishikawa E, Abe T, Ouchi A, Nagaoka S, Murata K, Miyazawa T, Nakagawa K. 2015. Kinetic study of the quenching reaction of singlet oxygen by seven rice bran extracts in ethanol solution. Development of a singlet oxygen absorption capacity (SOAC) assay method. Biosci Biotechnol Biochem 79: 2063-2072.

29) Fahrenholtz SR, Doleiden FH, Trozzolo AM, Lamols AA. 1974. On the quenching of singlet oxygen by $\alpha$-tocopherol. Photochem Photobiol 20: 505-509.

30) Beutner S, Bloedorn B, Frixel S, Blanco IH, Hoffmann T, Martin H-D, Mayer B, Noack P, Ruck C, Schmidt M, Schulke I, Sell S, Ernst H, Haremza S, Seybold G, Sies H, Stahl W, Walsh R. 2001. Quantitative assessment of antioxidant properties of natural colorants and phytochemicals: carotenoids, flavonoids, phenols and indigoids. The role of $\beta$-carotene in antioxidant functions. J Sci Food Agric 81: 559-568.

31) Ouchi A, Aizawa K, Iwasaki Y, Inakuma T, Terao J, Nagaoka S, Mukai K. 2010. Kinetic study of the quenching reaction of singlet oxygen by carotenoids and food extracts in solution. Development of a singlet oxygen absorption capacity (SOAC) assay method. J Agric Food Chem 58: 9967-9978.

32) Aizawa K, Iwasaki Y, Ouchi A, Inakuma T, Nagaoka S, Terao J, Mukai K. 2011. Development of singlet oxygen absorption capacity (SOAC) assay method. 2. Measurements of the SOAC values for carotenoids and food extracts. J Agric Food Chem 59: 3717-3729.

33) Mukai K, Ouchi A, Takahashi S, Aizawa K, Inakuma T, Terao J, Nagaoka S. 2012. Development of singlet oxygen absorption capacity (SOAC) assay method. 3. Measurements of the SOAC values for phenolic antioxidants. J Agric Food Chem 60: 7905-7916.

34) Mukai K, Ishikawa E, Ouchi A, Nagaoka S, Suzuki T, Izumisawa K, Koike T. 2014. Kinetic study of the quenching reaction of singlet oxygen by $\alpha-, \beta-, \gamma-, \delta$-tocotrienols and palm oil and soybean extracts in solution. Biosci Biotechnol Biochem 78: 2089-2101.

35) Iwasaki Y, Takahashi S, Aizawa K, Mukai K. 2015. Development of singlet oxygen absorption capacity (SOAC) assay method. 4. Measurements of the SOAC values for vegetable and fruit extracts. Biosci Biotechnol
Biochem 79: 280-291.

36) Mukai K, Ohara A, Junya I, Hirata M, Kobayashi E, Nakagawa K, Nagaoka S. 2019. Kinetic study of the quenching reaction of singlet oxygen by eight vegetable oils in solution. J Oleo Sci 68: 21-31.

37) Mukai K, Ouchi A, Azuma N, Takahashi S, Aizawa K, Nagaoka S. 2017. Development of a singlet oxygen absorption capacity (SOAC) assay method. Measurements of the SOAC values for carotenoids and $\alpha$-tocopherol in an aqueous Triton X-100 micellar solution. J Agric Food Chem 65: 784-792.

38) Mukai K, Ishikawa E, Ouchi A, Nagaoka S, Abe K, Suzuki T, Izumisawa K. 2018. Measurements of singlet oxygen quenching activity of vitamin E homologues and palm oil and soybean extracts in a micellar solution. Lipids 53: 601-613.

39) Takahashi S, Iwasaki-Kino Y, Aizawa K, Terao J, Mukai K. 2016. Development of singlet oxygen absorption capacity (SOAC) assay method using a microplate reader. J AOAC Int 99: 193-197.

40) Takahashi S, Tsutsumi A, Aizawa K, Suganuma H. 2018. Daily radical scavenging and singlet oxygen quenching capacity intake from fruits and vegetables in Japan. Food Sci Technol Res 24: 921-933.

41) Wakagi M, Watanabe J, Takahashi S, Yasui A, TakanoIshikawa Y. 2017. Inter-laboratory validation study of a singlet oxygen absorption capacity assay method for determining the antioxidant capacities of antioxidant solutions and food extracts. Food Sci Technol Res 23: 481-485.

42) Young RH, Wehrly K, Martin RL. 1971. Solvent effects in dye-sensitized photooxidation reactions. J Am Chem Soc 93: 5774-5779.

43) Thomas MJ, Foote CS. 1978. Chemistry of singlet oxygen XXVI. Photooxygenation of phenols. Photochem Photobiol 27: 683-693.

44) Wilkinson F, Helman WP, Ross AB. 1995. Rate constants for the decay and reactions of the lowest electronically excited singlet state of molecular oxygen in solution. An expanded and revised compilation. J Phys Chem Ref Data 24: 663-1021.

45) Britton G. 1995. Chapter 2, UV/visible spectroscopy. In: Carotenoids, Vol 1B: Spectroscopy (Britton G, LiaaenJensen S, Pfander H, eds), p 13-62. Birkhauser Verlag, Basel, Switzerland.

46) Tanielian C, Wolf C. 1988. Mechanism of physical quenching of singlet molecular oxygen by chlorophylls and related compounds of biological interest. Photochem Photobiol 48: 277-280.

47) Hertog MGL, Feskens EGM, Lollman PCH, Katan MB, Kromhout D. 1993. Dietary antioxidant flavonoids and risk of coronary heart disease: the Zutphen Elderly Study. Lancet 342: 1007-1011.

48) Nagai S, Ohara K, Mukai K. 2005. Kinetic study of the quenching reaction of singlet oxygen by flavonoids in ethanol solution. J Phys Chem B 109: 4234-4240.

49) Gruszka J, Pawlak A, Kruk J. 2008. Tocochromanols, plastoquinol, and other biological prenyllipids as singlet oxygen quenchers-determination of singlet oxygen quenching rate constants and oxidation products. Free Radical Biol Med 45: 920-928.

50) Battino R, ed. 1981. Oxygen and Ozone: Solubility Data Series, Vol 7, p 1-40. Pergamon Press, Oxford.

51) Cantrell A, McGarvey DJ, Truscott TG, Rancan F, Böhm F. 2003. Singlet oxygen quenching by dietary carotenoids 
in a model membrane environment. Arch Biochem Biophys 412: 47-54.

52) Fukuzawa K. 2000. Singlet oxygen scavenging in phospholipid membranes. Methods Enzymol 319: 101-110.

53) Fukuzawa K, Inokami $Y$, Tokumura A, Terao J, Suzuki A. 1998. Rate constants for quenching singlet oxygen and activities for inhibiting lipid peroxidation of carotenoids and $\alpha$-tocopherol in liposomes. Lipids 33: 751-756.

54) Niki E. 2012. Tocotrienols: Vitamin E beyond Tocopherols (Tan B, Watson R, Preedy V, eds), 2nd ed. CRC/AOCS Press, Boca Raton, and references are cited therein.

55) Shibata A, Nakagawa K, Kawakami Y, Tsuzuki T, Miyazawa T. 2010. Suppression of $\gamma$-tocotrienol on UVB induced inflammation in HaCaT keratinocytes and HR-1 hairless mice via inflammatory mediators multiple signaling. J Agric Food Chem 58: 7013-7020, and references are cited therein.

56) Mukai K, Tokunaga A, Itoh S, Kanesaki Y, Ohara K, Nagaoka S, Abe K. 2007. Structure-activity relationship of the free-radical-scavenging reaction by vitamin $\mathrm{E}(\alpha-$, $\beta-, \gamma-, \delta$-tocopherols) and ubiquinol-10: $\mathrm{pH}$ dependence of the reaction rates. J Phys Chem B 111: 652-662, and references are cited therein.
57) Yang CS, Chen L, Lee M-J, Balentine D, Kuo MC, Schantz SP. 1998. Blood and urine levels of tea catechins after ingestion of different amounts of green tea by human volunteers. Cancer Epidemiol Biomerkers Prev 7: 351354, and references are cited therein.

58) Cao G, Alessio HM, Cutler RG. 1993. Oxygen-radical absorbance capacity assay for antioxidants. Free Radical Biol Med 14: 303-311.

59) Ou B, Hampsch-Woodill M, Prior RL. 2001. Development and validation of an improved oxygen radical absobance capacity assay using fluorescein as the fluorescent probe. J Agric Food Chem 49: 4619-4626.

60) Huang D, Ou B, Hampsch-Woodill M, Flanagan JA, Deemer EK. 2002. Development and validation of oxygen radical absorbance capacity assay for lipophilic antioxidants using randomly methylated $\beta$-cyclodextrin as the solubility enhancer. J Agric Food Chem 50: 1815-1821.

61) Umeno A, Biju V, Yoshida Y. 2017. In vivo ROS production and use of oxidative stress-derived biomarkers to detect the onset of diseases such as Alzheimer's disease, Parkinson's disease, and diabetes. Free Radical Res 51: 413-427, and references are cited therein. 